\title{
Landscape and regional impacts of hurricanes in Puerto Rico
}

\section{Citation}

Boose, Emery R., Mayra I. Serrano, and David R. Foster. 2004. Landscape and regional impacts of hurricanes in Puerto Rico. Ecological Monographs 74, no. 2: 335-352. doi:10.1890/02-4057.

\section{Published Version}

doi:10.1890/02-4057

\section{Permanent link}

http://nrs.harvard.edu/urn-3:HUL.InstRepos:29394998

\section{Terms of Use}

This article was downloaded from Harvard University's DASH repository, and is made available under the terms and conditions applicable to Other Posted Material, as set forth at http:// nrs.harvard.edu/urn-3:HUL.InstRepos:dash.current.terms-of-use\#LAA

\section{Share Your Story}

The Harvard community has made this article openly available.

Please share how this access benefits you. Submit a story.

Accessibility 


\title{
LANDSCAPE AND REGIONAL IMPACTS OF HURRICANES IN PUERTO RICO
}

\author{
Emery R. Boose, ${ }^{1}$ Mayra I. Serrano, ${ }^{2}$ And David R. Foster \\ Harvard Forest, Harvard University, Petersham, Massachusetts 01366 USA
}

\begin{abstract}
Puerto Rico is subject to frequent and severe impacts from hurricanes, whose long-term ecological role must be assessed on a scale of centuries. In this study we applied a method for reconstructing hurricane disturbance regimes developed in an earlier study of hurricanes in New England. Patterns of actual wind damage from historical records were analyzed for 85 hurricanes since European settlement in 1508. A simple meteorological model (HURRECON) was used to reconstruct the impacts of 43 hurricanes since 1851. Long-term effects of topography on a landscape scale in the Luquillo Experimental Forest (LEF) were simulated with a simple topographic exposure model (EXPOS).

Average return intervals across Puerto Rico for F0 damage (loss of leaves and branches) and F1 damage (scattered blowdowns, small gaps) on the Fujita scale were 4 and 6 years, respectively. At higher damage levels, a gradient was created by the direction of the storm tracks and the weakening of hurricanes over the interior mountains. Average return intervals for F2 damage (extensive blowdowns) and F3 damage (forests leveled) ranged from 15 to 33 years and 50 to 150 years, respectively, from east to west. In the LEF, the combination of steep topography and constrained peak wind directions created a complex mosaic of topographic exposure and protection, with average return intervals for F3 damage ranging from 50 years to $>150$ years. Actual forest damage was strongly dependent on land-use history and the effects of recent hurricanes. Annual and decadal timing of hurricanes varied widely. There was no clear centennial-scale trend in the number of major hurricanes over the historical period.
\end{abstract}

Key words: Caribbean; Fujita scale; historical record; hurricane; landscape patterns; modeling; natural disturbance; Puerto Rico; regional patterns; topographic exposure; tropical forests; wind damage.

\section{INTRODUCTION}

Puerto Rico and neighboring islands of the Caribbean are subject to frequent and severe impacts from hurricanes, including wind damage to forests, scouring and flooding of river channels, landslides triggered by heavy rains, and salt water inundation along shorelines (Dunn and Miller 1964, Simpson and Riehl 1981, Diaz and Pulwarty 1997). The intensity of wind damage to forest stands is often highly variable, ranging from leaf stripping and branch break to individual tree gaps to extensive blowdowns. At larger spatial scales, complex patterns of damage often result from the interaction of meteorological, topographic, and biological factors (Boose et al. 1994). Long-term impacts to forests may include sudden or delayed tree mortality, changes in regeneration method and successional direction, increased species turnover and age class diversity, faster biomass and nutrient turnover, and greater belowground biomass allocation and carbon storage (Lugo 2000).

Manuscript received 10 July 2002; revised and accepted 13 May 2003; final version received 3 July 2003. Corresponding Editor: W. K. Lauenroth.

${ }^{1}$ E-mail: boose@fas.harvard.edu

${ }^{2}$ Present address: 1 Park Street, Boston, Massachusetts 02108 USA.
In recent years, our understanding of the short-term $(<10$-year) impacts of a single hurricane on the wet forests of Puerto Rico has advanced greatly, especially through intensive field studies of Hurricane Hugo (1989) as part of the Luquillo LTER program (e.g., Walker et al. 1991, 1996). After Hugo, for example, the Tabonuco forests of the Luquillo Experimental Forest (LEF) were found to exhibit remarkable resilience to wind damage: despite major structural reorganization, there was rapid regeneration of canopy cover through releafing, sprouting, or recruitment, which helped to reduce impacts on soil moisture, temperature, and nutrient-cycling processes (Walker 1991, Zimmerman et al. 1994, Scatena et al. 1996). Nutrient retention was high despite initial export pulses (Steudler et al. 1991, Silver et al. 1996). Key ecosystem elements showed a range of responses over the first five years, including rapid or gradual increase and return to normal levels (e.g., forest floor biomass and net primary productivity, respectively); as well as rapid decline followed by a rise to above-normal levels (e.g., aboveground pools of $\mathrm{K}$ and $\mathrm{Mg}$ ), a return to near-normal levels (e.g., tree biomass), a slow increase to belownormal levels (e.g., total fine litterfall), or little recovery (e.g., fine-root biomass) (Zimmerman et al. 1996).

The results of such field studies must be considered in a longer temporal context. Indeed, the frequency of 


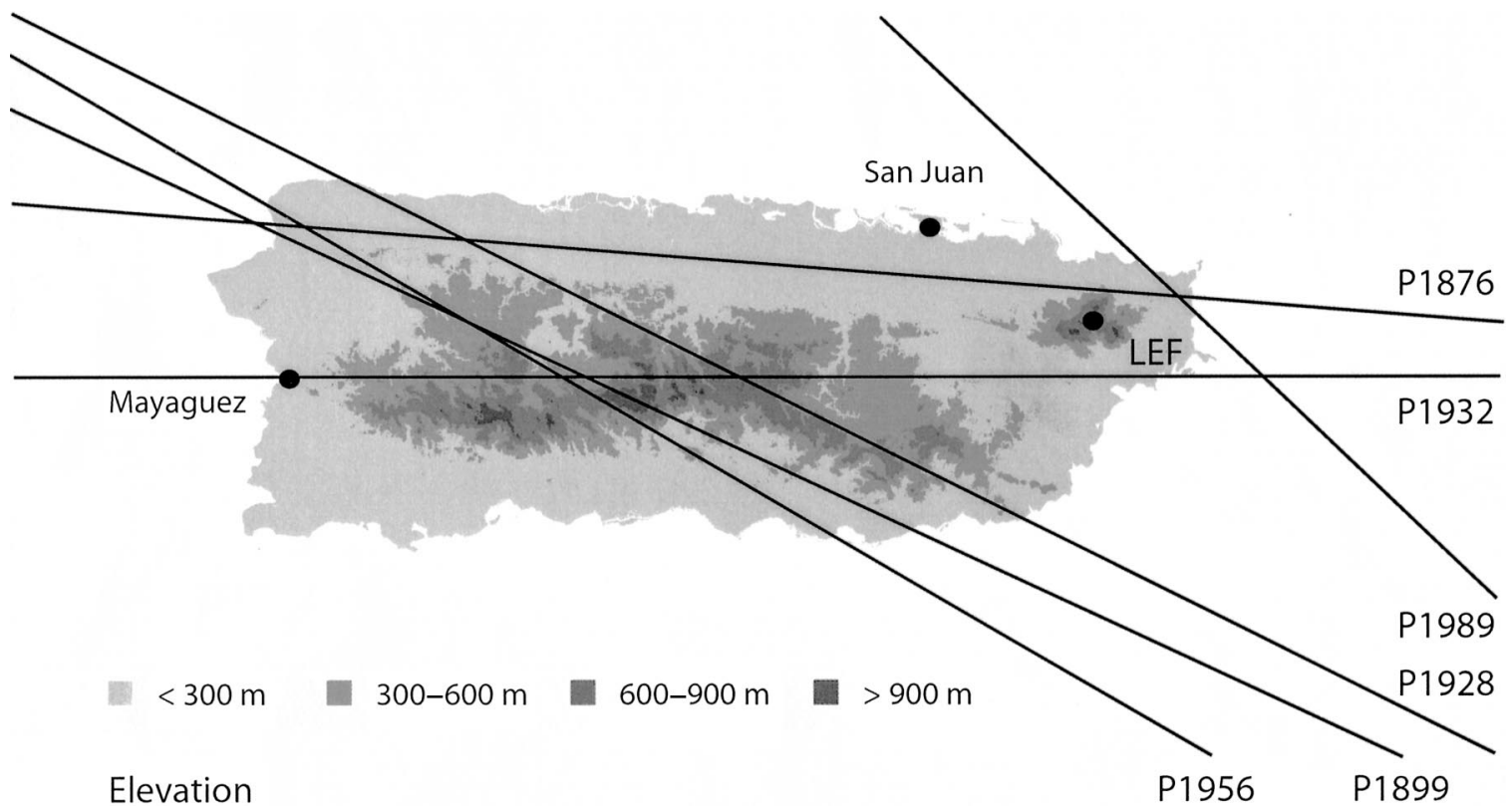

FIG. 1. Tracks of six hurricanes that caused F3 damage on the Fujita scale (see Table 1) during the period $1851-1997$. LEF is the Luquillo Experimental Forest.

hurricanes, the life span of trees, and the lags and legacies inherent in ecological systems are such that the long-term impacts of hurricanes on forests can be understood only on a scale of centuries. Such a temporal scale is needed to identify the natural range in disturbance intensity over space and time. The effects of a single hurricane lasting several hours may persist for decades (Foster et al. 1998). Moreover, the impacts of successive hurricanes are not necessarily independent, because forest susceptibility to wind damage is strongly influenced by composition and structure, which in turn are strongly influenced by previous disturbance and land use (Foster and Boose 1992). Although the history of hurricanes in Puerto Rico and the Caribbean has been documented in several studies (e.g., Salivia 1950, Millas 1968), and simple indices of hurricane impacts for particular sites have been proposed (e.g., Scatena and Larsen 1991), estimates in the ecological literature of hurricane frequency and intensity in Puerto Rico vary widely and a comprehensive study based on meteorological principles and the historical record is lacking.

In an earlier study of New England hurricanes, we developed a method for reconstructing hurricane regimes using a combination of historical research and computer modeling (Boose et al. 2001). In the present study, we apply this method to quantify the impacts of hurricane winds in Puerto Rico over a period of 490 years since European settlement. Our results provide the most accurate estimate to date of long-term hurricane impacts in Puerto Rico, as well as an historical context in which to place intensive studies of recent hurricanes. Although land use has emerged as a critical factor shaping the structure and function of present- day forests in much of Puerto Rico (Foster et al. 1999), protected forests of the future, like those of the past, will be largely shaped by the hurricane disturbance regime described in this study. The HURRECON and EXPOS models and the historical data used in our analysis of Puerto Rican hurricanes are available on the Harvard Forest web page. ${ }^{3}$

\section{Study Area \\ Puerto Rico}

Puerto Rico, the easternmost and smallest of the Greater Antilles, is a mountainous island roughly 55 $\times 160 \mathrm{~km}$ in size (Fig. 1). Mountain ranges include the Cordillera Central extending across the island from west to southeast (maximum elevation $1338 \mathrm{~m}$ ), and the Sierra de Luquillo in the northeast (maximum elevation $1074 \mathrm{~m}$ ), site of the LEF. Considerable variation in climate is caused by the interaction of topography and the prevailing northeasterly trade winds. Annual precipitation ranges from $750 \mathrm{~mm}$ in the southwest to $1500-2000 \mathrm{~mm}$ in the northeast to more than $4000 \mathrm{~mm}$ in the higher elevations of the LEF (Birdsey and Weaver 1982). Major life zones include Subtropical Dry Forest in the southwest, Subtropical Moist Forest elsewhere at lower elevations, Subtropical Wet Forest and Rain Forest at higher elevations, and Lower Montane Wet Forest and Rain Forest near the highest summits (Holdridge 1946, Ewel and Whitmore 1973). Politically the island is divided into 78 municipalities (municipios) that include the neighboring islands of Culebra and Vieques and range in area from 13 to $330 \mathrm{~km}^{2}$.

\footnotetext{
${ }^{3}$ URL: 〈http://harvardforest.fas.harvard.edu $\rangle$
} 


\section{Hurricanes in Puerto Rico}

Hurricane frequency in Puerto Rico is among the highest in the North Atlantic basin (Neumann et al. 1987). Most storms approach from the east and southeast (Fig. 1). Although hurricanes sometimes originate close to the island, the most intense storms often form off the west coast of Africa and reach Puerto Rico at or near maximum intensity. Impacts on both human and natural systems can be devastating. For example, in the San Felipe storm of 1928, a category 5 hurricane on the Saffir-Simpson scale, winds of hurricane force ( $\geq 33 \mathrm{~m} / \mathrm{s}$ ) lasted $12-18$ hours across much of the island, with peak winds measured at $72 \mathrm{~m} / \mathrm{s}$ in San Juan (before the anemometer blew apart); rainfall exceeded $640 \mathrm{~mm}$ in the higher terrain and some towns near the center of the storm were practically leveled (Fassig 1928); forests at higher elevations were almost completely destroyed (Bates 1930). The catastrophic loss of life in Puerto Rican hurricanes until recent decades, including more than 3000 people in the San Ciriaco hurricane of 1899, resulted mainly from river flooding and, to a lesser extent, from building collapse. The mountainous topography of the island affects both the overall intensity of hurricanes that make landfall as well as the extent of local protection from damaging winds.

\section{Methods}

\section{Historical data}

Damage data.-Principal sources of wind damage data were as follows: (1) for the period 1876-1997, contemporary Puerto Rican newspapers, especially Boletin Mercantil de Puerto Rico, Correspondencia de Puerto Rico, La Democracia, El Imparcial, El Mundo, El Nuevo Dia, Porto Rico Progress, Puerto Rico Ilustrado, El Regionalista, The San Juan Star, and El Vocero, with Salivia (1950) providing valuable secondary information; (2) for the period 1508-1875, secondary studies, especially Salivia (1950) and Millas (1968), as well as Asenjo (1886), Brau (1904), Van Middeldyk (1910), and Coll y Toste (1914-1927). These works were supplemented wherever possible by primary sources (letters and other documents) from the Archivo de Indias at the University of Puerto Rico in Rio Piedras and from the General Archives of Puerto Rico in San Juan. Efforts were focused on obtaining a good map of wind damage across Puerto Rico for each hurricane.

Meteorological data.-Principal sources of meteorological data were as follows. (1) For the period 18511997, the HURDAT (Hurricane Data) database maintained by the U.S. National Hurricane Center, which provides location and maximum sustained (1-min) wind speed every six hours for Atlantic hurricanes (Jarvinen et al. 1984). HURDAT data for 1871-1992 were retrieved from the Global Tropical/Extratropical Cyclone Climatic Atlas (NOAA 1994), and for 1993-1997 from the National Hurricane Center web page. ${ }^{4}$ Hurricane tracks before 1871 were obtained from Fernandez-Partagas and Diaz (1995); these data have recently been incorporated into HURDAT (Landsea et al. 2002). Studies of individual hurricanes in the Monthly Weather Review were consulted, and surface-wind observations at San Juan were obtained from the U.S. National Climatic Data Center for seven hurricanes since 1899. (2) For the period 1508-1850, meteorological reconstructions were not attempted in the absence of reliable estimates of hurricane tracks. Such estimates, which would require extensive analysis of historical reports from surrounding islands and ships at sea, may become available in the future (C. Landsea, personal communication) but were beyond the scope of this project.

Hurricane selection.-Historical evidence was examined for all hurricanes that met the following criteria: (1) for the period 1851-1997, tropical cyclones that passed within $500 \mathrm{~km}$ of Puerto Rico with sustained winds of hurricane force $(\geq 33 \mathrm{~m} / \mathrm{s})$ according to HURDAT; (2) for the period 1508-1850, hurricanes that impacted Puerto Rico according to Saliva (1950), Millas (1968), or the other secondary studies previously listed. In total, 143 hurricanes were investigated. Of these, 85 hurricanes for which we found historical evidence of wind damage in Puerto Rico (F0 or higher on the Fujita scale; see next section) were selected for detailed study.

\section{Actual damage 1508-1997}

Fujita scale.-Actual wind damage in each hurricane was classified using Fujita's $(1971,1987)$ system for assessing wind damage in tornadoes and hurricanes. This system has been used by the U.S. National Weather Service for tornadoes since the early 1970s (Grazulis 1993). Fujita's damage classes extend from F0 (minor damage caused by gale or storm force winds) to F5 (extreme damage in the most severe tornadoes). Each F-scale (Fujita scale) class is defined by specified levels of damage to common cultural and biological features of the landscape. The system was designed for rapid application in the field and does not require detailed engineering analysis.

For this study, Fujita's system was modified and extended slightly for better application to Puerto Rico (Table 1; cf. Boose et al. 2001). Changes were based, in part, on the work of Grazulis (1993) and, in part, on historical evidence of comparable damage in the hurricanes studied. The following changes were most important. (1) Trees: blowdowns were classified as F0 only if the trees were described as weak. Fujita regarded the pushing over of shallow-rooted trees as F0, but in most cases it was impossible to determine the condition of the tree from the historical reports. (2) Roofs: partial removal of a roof was not distinguished

\footnotetext{
${ }^{4}$ URL: 〈http://www.nhc.noaa.gov $\rangle$
} 
TABle 1. The Fujita scale of wind damage, modified for application to Puerto Rico.

\begin{tabular}{|c|c|c|c|c|}
\hline \multirow[b]{2}{*}{ Measure } & \multicolumn{4}{|c|}{ Fujita rating } \\
\hline & F0 damage & F1 damage & F2 damage & F3 damage \\
\hline $\begin{array}{l}\text { Sustained wind speed } \\
\qquad(\mathrm{m} / \mathrm{s}) \dagger\end{array}$ & $18-25$ & $26-35$ & $36-47$ & $48-62$ \\
\hline Trees & $\begin{array}{l}\text { leaves and fruit } \\
\text { off, branches } \\
\text { broken, trees } \\
\text { damaged }\end{array}$ & trees blown down & extensive blowdowns & most trees down \\
\hline Crops & $\begin{array}{l}\text { damaged or blown } \\
\text { down }\end{array}$ & & & \\
\hline Wood-zinc houses $\ddagger$ & minor damage & unroofed or damaged & $\begin{array}{l}\text { blown down or de- } \\
\text { stroyed }\end{array}$ & $\begin{array}{l}50 \% \text { or more blown } \\
\text { down or destroyed }\end{array}$ \\
\hline Masonry buildings & minor damage & $\begin{array}{l}\text { roof peeled, windows } \\
\text { broken, chimneys } \\
\text { down }\end{array}$ & unroofed & $\begin{array}{l}\text { blown down or de- } \\
\text { stroyed }\end{array}$ \\
\hline $\begin{array}{l}\text { Wood houses, } \| \text { munici- } \\
\text { pal buildings }\end{array}$ & minor damage & $\begin{array}{l}\text { roof peeled, windows } \\
\text { broken, chimneys } \\
\text { down }\end{array}$ & unroofed or destroyed & $\begin{array}{l}3+\text { blown down or de- } \\
\text { stroyed }\end{array}$ \\
\hline $\begin{array}{l}\text { Cabins, outbuildings, } \\
\text { warehouses }\end{array}$ & minor damage & $\begin{array}{l}\text { unroofed, blown down } \\
\text { or destroyed }\end{array}$ & & \\
\hline HutsI & damaged & $\begin{array}{l}\text { blown down or de- } \\
\text { stroyed }\end{array}$ & & \\
\hline $\begin{array}{l}\text { Furniture, bedding, } \\
\text { clothes }\end{array}$ & not moved & blown out of building & & \\
\hline $\begin{array}{l}\text { Masonry walls, radio } \\
\text { towers, traffic lights }\end{array}$ & no damage & blown down & & \\
\hline Utility poles & wires down & $\begin{array}{l}\text { poles damaged or } \\
\text { blown down, high- } \\
\text { tension wires down }\end{array}$ & & \\
\hline Signs, fences & damaged & blown down & & \\
\hline Autos & no damage & $\begin{array}{l}\text { moving autos pushed } \\
\text { off road }\end{array}$ & $\begin{array}{l}\text { stationary autos moved } \\
\text { or pushed over }\end{array}$ & $\begin{array}{l}\text { heavy autos lifted and } \\
\text { thrown }\end{array}$ \\
\hline Trains & no damage & pushed along tracks & boxcars pushed over & trains overturned \\
\hline Marinas, small airplanes & minor damage & destroyed & & \\
\hline Small boats & $\begin{array}{l}\text { blown off moor- } \\
\text { ing }\end{array}$ & sunk & & \\
\hline Missiles & none & none & $\begin{array}{l}\text { light objects, metal } \\
\text { roofs }\end{array}$ & \\
\hline
\end{tabular}

$\dagger$ Sustained wind speed values are derived from Fujita's equations (1971), assuming a wind gust factor of 1.5 over land. \$ Also barns, town halls, wood churches, schools, sugar mills, commercial buildings, military buildings, and unspecified buildings.

$\S \mathrm{F} 2$ was assigned if buildings were described as rural or poor.

|l Wood-frame houses described as well-constructed or owned by a wealthy person.

II Constructed of palm leaves or similar materials.

from complete removal. Fujita required that the entire roof of a wood house be removed to qualify for F2 damage, but in most cases it was impossible to determine exactly how much of the roof was blown off. (3) Wood houses: only houses described as well-constructed or owned by a wealthy person were regarded as equivalent to Fujita's wood-frame house. F3 was assigned if at least three such houses in the same municipality were completely blown down; this restriction was added to increase the likelihood that at least one of the three houses was well-built and in good condition. (4) Wood-zinc houses: Puerto Rican houses are often built with a light wood frame and zinc-plated metal roof (or thatch, before the late 19th century; Jopling 1988). Such buildings were found to sustain damage comparable to barns in Fujita's system. Munici- palities were assigned F3 damage if at least half of the wood-zinc houses were completely blown down (unless described as rural or poor). Such cases were often accompanied by other evidence of F3 damage. (5) Huts: simple huts constructed of palm leaves or similar materials are easily damaged by high winds. Damage to such buildings was classified as F0 and blowdown or destruction as F1.

Database and map compilation.--Reports of wind damage were collected and indexed by municipality to create a database for each hurricane. Each report that contained sufficient information was assigned an Fscale value based on the highest level of damage reported. Care was taken to exclude coastal damage caused by the storm surge, valley damage caused by river flooding, and local damage caused by landslides. 


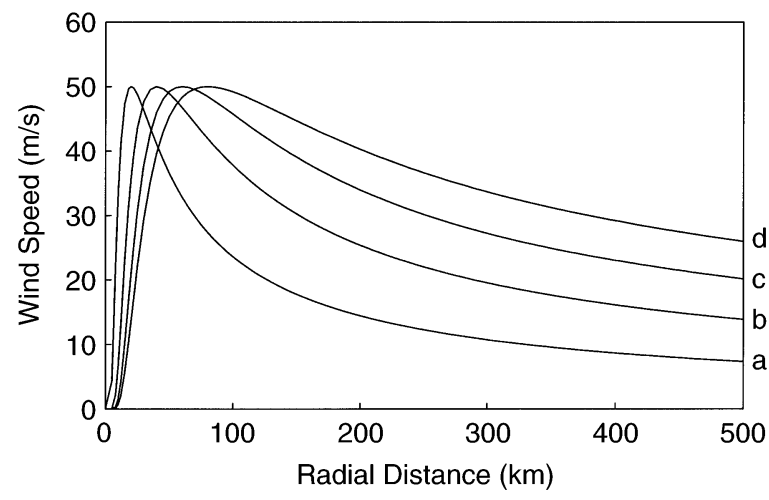

FIG. 2. HURRECON model. The estimated wind speed along a radial line outward from the storm center is a function of the radius of maximum winds $\left(R_{\mathrm{m}}\right)$, the wind speed at that radius $\left(V_{\mathrm{rm}}\right)$, and the scaling parameter $B$, which controls the shape of the curve. Each hurricane was modeled using four combinations of $R_{\mathrm{m}}$ and $B$ : (a) $20 \mathrm{~km}, 1.5$; (b) $40 \mathrm{~km}, 1.4$; (c) $60 \mathrm{~km}, 1.3$; and (d) $80 \mathrm{~km}, 1.2$. Wind velocity curves are shown for an arbitrary value of $V_{\mathrm{rm}}=50 \mathrm{~m} / \mathrm{s}$

Maps of actual wind damage across Puerto Rico were then created for each hurricane, assigning to each municipality the maximum F-scale value from all reports for that municipality. Reports from larger areas (e.g., the entire island) were assigned F-scale values, but were not used in the creation of the damage maps. Map resolution was $0.5 \mathrm{~km}$.

\section{Meteorological reconstructions 1851-1997}

HURRECON model.-A simple meteorological model (HURRECON; Boose et al. 1994, 1997, 2001), based on published empirical studies of many hurricanes, was used to reconstruct the impacts of each storm. HURRECON uses information on the track, size, and intensity of a hurricane, as well as the cover type (land or water), to estimate surface wind speed and direction. The model also estimates wind damage on the Fujita scale by using the correlation between maximum 0.25-mile wind velocity (i.e., maximum wind velocity sustained over a 0.25 -mile $[\sim 0.40-\mathrm{km}]$ distance) and wind damage proposed by Fujita (1971; see Table 1).

Model equations follow. Wind velocity and direction are measured relative to the Earth's surface, and angles are measured in degrees. Parameter values used in this study are given in parentheses. The sustained wind velocity $\left(V_{\mathrm{s}}\right)$ at any point $P$ in the northern hemisphere is estimated as

$$
\begin{aligned}
V_{\mathrm{s}}= & F\left[V_{\mathrm{m}}-S(1-\sin T) V_{\mathrm{h}} / 2\right] \\
& \times\left[\left(R_{\mathrm{m}} / R\right)^{B} \exp \left(1-\left[R_{\mathrm{m}} / R\right]^{B}\right)\right]^{1 / 2}
\end{aligned}
$$

where $F$ is the scaling parameter for effects of friction (water $=1.0$, land $=0.8), V_{\mathrm{m}}$ is the maximum sustained wind velocity over water anywhere in the hurricane, $S$ is the scaling parameter for asymmetry due to forward motion of storm (1.0), $T$ is the clockwise angle between the forward path of hurricane and a radial line from hurricane center to point $P, V_{\mathrm{h}}$ is the forward velocity of the hurricane, $R_{\mathrm{m}}$ is the radius of maximum winds $(20-80 \mathrm{~km}), R$ is the radial distance from the hurricane center to point $P$, and $B$ is the scaling parameter controlling the shape of the wind profile curve (1.2-1.5). This equation was adapted from Holland's equation for the cyclostrophic wind (Holland 1980: Eq. 5). The peak wind gust velocity $\left(V_{\mathrm{g}}\right)$ at point $P$ is estimated from $V_{\mathrm{s}}$ as

$$
V_{\mathrm{g}}=G V_{\mathrm{s}}
$$

where $G$ is the gust factor (water $=1.2$, land $=1.5$ ). The maximum 0.25 -mile wind velocity $\left(V_{\mathrm{f}}\right)$ is estimated from $V_{\text {s }}$ and $G$ using Fujita's method (Fujita 1971: Eq. $12)$. Wind direction $(D)$ at point $P$ is estimated as

$$
D=A_{z}-90-I
$$

where $A_{z}$ is the azimuth from point $P$ to the hurricane center, and $I$ is the cross isobar inflow angle (i.e., the angle between the inwardly spiraling surface wind and the circular isobars around the hurricane center: water $=20^{\circ}$, land $=40^{\circ}$ ). In the southern hemisphere, where the wind circulation is clockwise around the center, $T$ is the counterclockwise angle between the forward path of the hurricane and a radial line from the hurricane center to point $P$, and $D=A_{z}+90+I$.

Parameterization and validation.-For this study, the HURRECON model was parameterized and tested as follows. (1) Parameters were assigned from the literature and adjusted as necessary in detailed studies of seven major hurricanes since 1899 (P1899, P1916a, P1928, P1931, P1932, P1956, P1989). These storms combined reasonably good meteorological data with extensive and well-documented wind damage. For each hurricane, model estimates were compared to actual wind and damage observations. The goal was to find parameters or a range of parameters that worked well for all seven storms. (2) The model thus parameterized was tested by comparing actual and reconstructed damage for the remaining 36 hurricanes since 1851, where damage data were independent of the (input) meteorological data.

Parameter values for $F, G$, and $I$ were adopted directly from published sources (Dunn and Miller 1964, Fujita 1971, Simpson and Riehl 1981, Powell 1982, 1987); $F$ and $G$ were chosen so that peak gust speeds are the same over water and land. The value $S=1.0$ (i.e., peak wind speed on the right side minus peak wind speed on the left side $=V_{\mathrm{h}}$ ) was adopted from an earlier study of New England hurricanes (Boose et al. 2001). The modeled wind profile (i.e., wind speed along a radial line) for a given value of $V_{\mathrm{m}}$ is controlled by the parameters $R_{\mathrm{m}}$ and $B$ (Fig. 2). However, direct measurements of the wind profile by aerial reconnaissance are available only for hurricanes since 1944 (Landsea 1993) and only for hurricanes over open water 
(H. Willoughby, personal communication). For this reason, and to test model sensitivity to these critical parameters, each storm was separately modeled for four combinations of $R_{\mathrm{m}}$ and $B$ chosen to span the range from very narrow to very wide storms: (1) $R_{\mathrm{m}}=20$ $\mathrm{km}, B=1.5$; (2) $40 \mathrm{~km}, 1.4$; (3) $60 \mathrm{~km}, 1.3$; and (4) $80 \mathrm{~km}, 1.2$. The combination of $R_{\mathrm{m}}$ and $B$ that produced the best agreement between actual and reconstructed damage across the island was selected for the final results.

Input variables for each model run included location of the storm center and maximum sustained wind velocity $\left(V_{\mathrm{m}}\right)$ at regular (6-h) intervals from HURDAT, with modifications described in the next section. Model runs for individual sites were made using a time step of $5 \mathrm{~min}$, and the cover type was assumed to be land. Regional estimates were made at $3-\mathrm{km}$ resolution using a time step equal to the minimum time required for each hurricane to traverse one $3 \times 3-\mathrm{km}$ grid cell in a regional study window adjusted to include the storm's closest approach to Puerto Rico.

Model reconstructions were tested by comparing actual and reconstructed F-scale wind damage across the island (Fig. 3). Such comparisons were quantified by creating and analyzing a difference map (reconstructed damage minus actual damage) for each storm. The difference maps provided a measure of the overall accuracy of each reconstruction as well as the spatial pattern of agreement. Reconstructed and observed surface wind speeds were also compared for seven major hurricanes since 1899. However, a detailed study of observed wind speeds, although desirable, was beyond the scope of this project. Accurate comparisons require careful correction of the observed wind speed for various factors including height of the anemometer, surface roughness over the approaching wind trajectory, and duration of measurement (Powell et al. 1994). In addition, wind observations were available for only one station in Puerto Rico (San Juan) for all but the most recent hurricanes.

Reconstructions.-Meteorological reconstructions were based on the HURDAT database, which, although widely used, has known deficiencies (including both systematic and random errors) and is currently under revision by NOAA (Landsea 1993, Neumann and McAdie 1997, Landsea et al. 2002). HURDAT 6-h wind speeds at landfall or closest approach to Puerto Rico were increased for 11 hurricanes and decreased for two hurricanes in order to reconcile significant differences between observed and reconstructed F-scale wind damage. The average increase was $10.8 \mathrm{~m} / \mathrm{s}$ (maximum 20.6 $\mathrm{m} / \mathrm{s}$ ) and the average decrease was $12.9 \mathrm{~m} / \mathrm{s}$ (maximum $15.4 \mathrm{~m} / \mathrm{s}$ ). Hourly wind speed adjustments for each hurricane are detailed in Appendix A. The track for Hurricane Betsy (P1956) was also moved $25 \mathrm{~km}$ to the southwest over Puerto Rico in order to improve spatial agreement between observed and reconstructed damage. These modifications were reported to NOAA and most have been recommended for inclusion in the upcoming revision of HURDAT (C. Landsea, personal communication).

Maps of actual damage showed evidence of storm weakening (at least at surface levels) in nearly all cases where hurricanes passed directly over the island. In a few recent cases, this weakening was confirmed by direct measurements; e.g., radar showed that the eye of Hurricane Betsy (P1956) became distorted over land, increasing in diameter from 10 to $45 \mathrm{~km}$ and tilting vertically in the direction of motion (Grace 1956). Such weakening was simulated for the 15 hurricanes that passed over the island by estimating $V_{\mathrm{m}}$ at landfall (from HURDAT values, modified as before) and then reducing $V_{\mathrm{m}}$ by $1.5 \mathrm{~m} / \mathrm{s}$ (3 knots) for each hour that the storm center remained over land (Appendix A). This rate corresponds to an increase in minimum pressure of $\sim 3 \mathrm{mb} / \mathrm{h}$ ( 11 units $300 \mathrm{~Pa} / \mathrm{h}$ ) for a category 3 hurricane (which is consistent with empirical observations; Anthes 1982); and slightly less than the average $2.1 \mathrm{~m} / \mathrm{s}$ ( 4 knots) per hour predicted by a recent empirical model for a comparable hurricane during the first four hours after landfall (Kaplan and DeMaria 1995).

At the regional scale, maps of reconstructed F-scale damage for each hurricane were compiled to generate maps showing the number of storms at a given minimum intensity (F0, F1, F2, or F3) for each $3 \times 3-\mathrm{km}$ cell. Each frequency map was divided by hand into $3-$ 4 regions, and an average return time was calculated for each region based on the average number of storms and the observation period. For two sites within the regional hurricane gradient, the LEF in the northeast and the city of Mayaguez on the west coast, model reconstructions were collated to create plots of reconstructed F-scale damage as a function of (1) time and (2) reconstructed peak wind direction. Landscape-level impacts in the LEF were explored with the EXPOS model (Boose et al. 1994, 2001) and an elevation map at $30-\mathrm{m}$ resolution (digitized from the 1:24 000 U.S. Forest Service map). A map of topographic exposure was created for each hurricane, using the reconstructed peak wind direction and an inflection angle of $6^{\circ}$. These maps were compiled to produce maps showing estimated average return intervals for F3 damage across the LEF.

\section{Results}

\section{Actual damage 1508-1997}

Damage reports.-As expected, the number of reports and the completeness of the resulting damage maps were greater for recent or severe hurricanes. Specific reports for the earliest hurricanes (before 1673) were confined to the capital city of San Juan. In general, the level of wind damage was consistent within reports and among reports for the same municipality. The maximum reported damage for each hurricane was distrib- 
a) Actual Damage
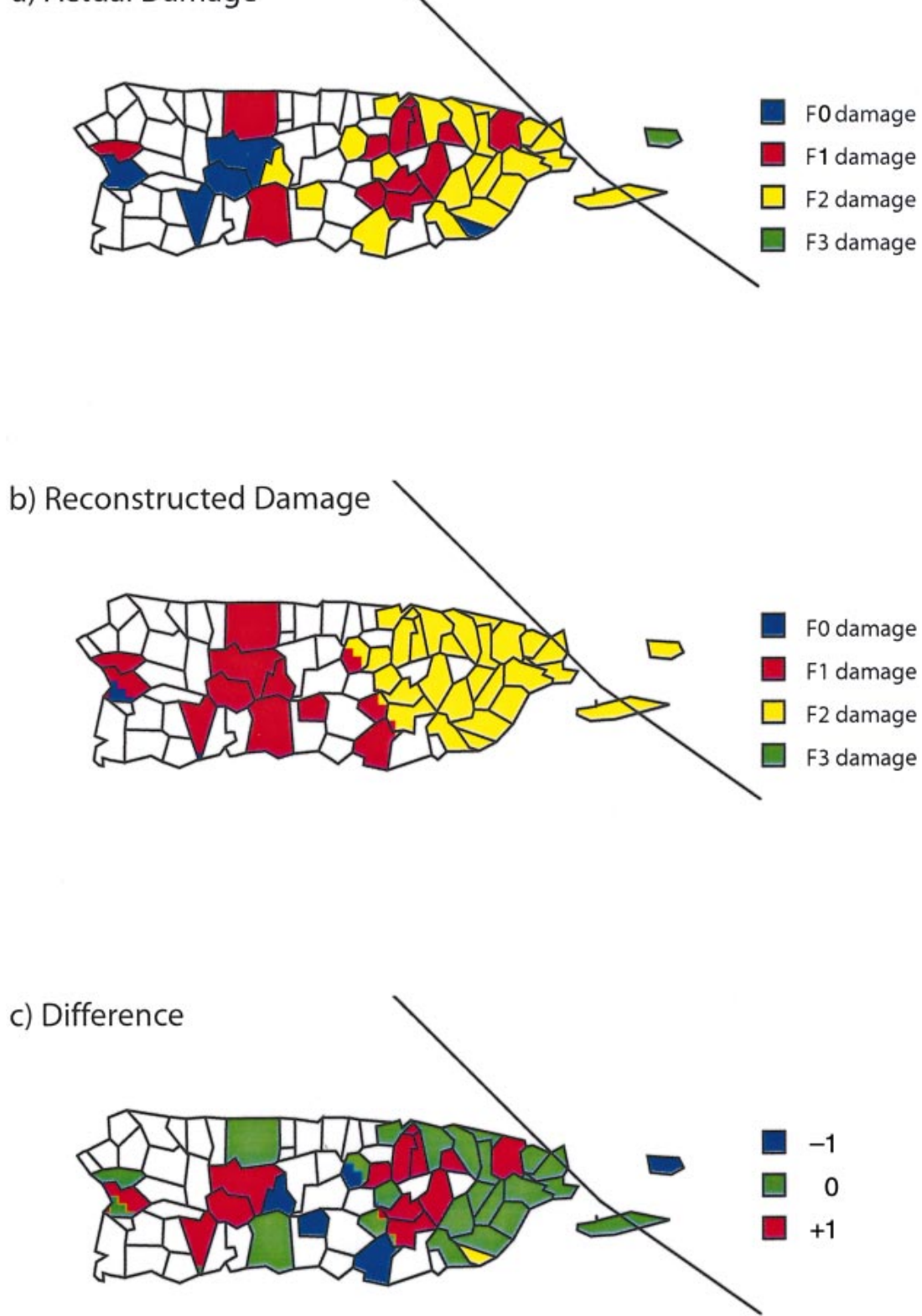

FIG. 3. Comparison of actual and reconstructed wind damage on the Fujita scale for Hurricane Hugo (P1989): (a) actual damage by municipality; (b) reconstructed damage for the same municipalities at 3-km resolution using the HURRECON model; (c) difference map showing reconstructed damage minus actual damage.

uted as follows: 12 hurricanes (14\%) with F0 damage; 28 hurricanes (33\%) with F1 damage; 31 hurricanes (37\%) with F2 damage; and 14 hurricanes (16\%) with F3 damage. Numbers of municipalities falling into each Fujita damage class for each hurricane are given in Appendix B.

Patterns of damage across the island created by individual hurricanes were consistent with meteorological expectations: (1) damage was usually somewhat greater to the right of the storm track, where wind velocities are normally higher; and (2) the intensity of damage usually lessened along the storm track for hurricanes that passed over the island (Fig. 4). For the most part, neighboring municipalities had similar F-scale values. In the most severe storms, buildings and forests were sometimes leveled over broad areas, with significant secondary damage and personal injury resulting from airborne missiles such as metal roofs.

Temporal variation.-Our analysis of temporal variation in Puerto Rican hurricanes was based on 73 hurricanes whose dates are known and whose maximum 
reported wind damage equaled or exceeded F1 on the Fujita scale (Table 2). On a seasonal scale, $84 \%$ of these hurricanes, including $86 \%$ of the hurricanes that caused F3 damage, occurred during the months of August and September (Fig. 5). On an annual scale, there were seven years in which two hurricanes in the same year caused F1 or F2 damage (1738, 1772, 1813, 1891, 1894, 1995, 1996); none of these storms caused F3 damage. From 1851 to 1997, the average interval between years in which hurricanes caused $\mathrm{F} 1+$ damage in Puerto Rico was 4.0 years, whereas the maximum interval since 1867 was 13 years (1876-1889). Note that these values apply to the entire island and not to any given site.

On a decadal scale, the number of hurricanes that caused F1+ damage in Puerto Rico since 1851 varied from a minimum of zero storms in the 1850 s to a maximum of seven storms in the 1890 s, with similar variation over the earlier historical period (Fig. 6). Historical reconstructions at other sites may help to confirm these patterns (for nearby sites) or to document regional differences (for more distant sites). For example, in the mid-19th century, a period of major cooling in the northern hemisphere (Mann et al. 1998), our studies suggest a lull in hurricane activity in Puerto Rico, with a matching decrease in the Yucatan (Boose et al. 2003) but an increase in New England (Boose et al. 2001). As our understanding of the links between hurricane activity and other global climatic factors improves (e.g., Gray 1990, Gray et al. 1997), hurricane activity may be added to existing proxies for past climatic conditions.

On a centennial scale, the number of F3 hurricanes was fairly constant over the historical period, with the greatest number (four storms) in the 19th and 20th centuries and the smallest number (one storm) in the 18 th century (Fig. 6). At lower damage levels, the number of F2 hurricanes increased steadily over time and the number of F1 hurricanes increased steadily until the 19th century. These trends are probably the result of improvements in meteorological observations and records, and the natural tendency to retain records of the most damaging storms. Little information is available for the F1 storms in the 15th and 16th centuries, and it is quite possible that one or more of these storms caused unreported F2 damage.

\section{Meteorological reconstructions 1851-1997}

Meteorological characteristics.-The intensity of the reconstructed hurricanes ranged from category 1 to category 5 on the Saffir-Simpson scale at the point of landfall or closest approach to Puerto Rico (Table 2). Twelve hurricanes $(28 \%)$ were category $1\left(V_{\mathrm{m}}=33-\right.$ $42 \mathrm{~m} / \mathrm{s}) ; 12$ hurricanes $(28 \%)$ were category $2\left(V_{\mathrm{m}}=\right.$ $43-49 \mathrm{~m} / \mathrm{s})$; eight hurricanes $(19 \%)$ were category 3 $\left(V_{\mathrm{m}}=50-58 \mathrm{~m} / \mathrm{s}\right)$; seven hurricanes $(16 \%)$ were category $4\left(V_{\mathrm{m}}=59-69 \mathrm{~m} / \mathrm{s}\right)$; and four hurricanes $(9 \%)$ were category $5\left(V_{\mathrm{m}}=\geq 70 \mathrm{~m} / \mathrm{s}\right)$. Fifteen of these hur- ricanes $(35 \%)$ made landfall in Puerto Rico. The bestfit values for $R_{\mathrm{m}}$ and $B$ combinations were as follows: $20 \mathrm{~km}, 1.5=$ six hurricanes $(14 \%) ; 40 \mathrm{~km}, 1.4=14$ hurricanes (33\%); $60 \mathrm{~km}, 1.3=16$ hurricanes $(37 \%)$; and $80 \mathrm{~km}, 1.2=$ seven hurricanes (16\%). Best-fit values for each hurricane are included in Appendix C.

Actual and reconstructed damage.-In most cases there was good agreement between actual and reconstructed F-scale damage by municipality. Reconstructed F-scale damage equaled actual damage in $52 \%$ of the cases, was within one damage class in $92 \%$ of the cases, and was within two damage classes in $99 \%$ of the cases. There was a tendency to overestimate damage (30\% of cases) rather than underestimate damage ( $18 \%$ of cases). Numbers of municipalities in each difference class (reconstructed damage minus actual damage) for each hurricane are given in Appendix C.

Spatial variation.-Because historical records are non-existent at many sites, and incomplete at all sites, our analysis of spatial variation in hurricane impacts was based on meteorological reconstructions of each storm using the HURRECON model. The frequency of F0 events was no doubt underestimated, because F0 damage could result from storms not included in this study; e.g., hurricanes that passed farther out to sea or tropical storms that did not attain hurricane strength.

At a regional scale, composite maps of individual hurricane reconstructions showed gradients of reconstructed frequency across Puerto Rico at the higher damage levels (Fig. 7). The mean return interval for F0 damage (loss of leaves and branches) or higher was $\sim 4$ years, and for F1 damage (scattered blowdowns, small gaps) or higher $\sim 6$ years; these values were fairly constant across the island. Mean return intervals for F2 damage (extensive blowdowns, large gaps) or higher ranged from $\sim 15$ years in Culebra, Vieques and the northeastern tip of the main island, to $\sim 33$ years in western sections. Mean return intervals for F3 damage (forests leveled) ranged from $\sim 50$ years in the northeast part of the island to $\sim 150$ years in western and central sections.

Analysis of model sensitivity to the parameters $R_{\mathrm{m}}$ and $B$ yielded the following range of values for the maximum number of storms causing F3 damage over some part of the island: five storms $(80 \mathrm{~km}, 1.2)$; three storms $(60 \mathrm{~km}, 1.3 ; 40 \mathrm{~km}, 1.4$; and best-fit combination), and two storms ( $20 \mathrm{~km}, 1.5)$; with corresponding mean return intervals of 29,49 , and 74 years, respectively. Thus estimated return intervals, if all storms were assumed to be very wide $(80 \mathrm{~km}, 1.2)$ or very narrow $(20 \mathrm{~km}, 1.5)$, were within $\sim 50 \%$ of the bestfit value for $R_{\mathrm{m}}$ and $B$.

At the site scale, time lines of reconstructed damage were created for the Luquillo Experimental Forest and the city of Mayaguez (Fig. 8). Although the temporal patterns are similar, there are important differences despite the fact that the sites are only $\sim 140 \mathrm{~km}$ apart. On average, hurricane damage is more frequent and 
a) P1899

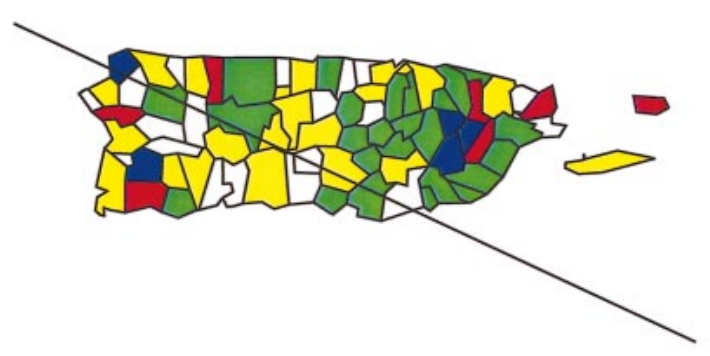

c) P1932

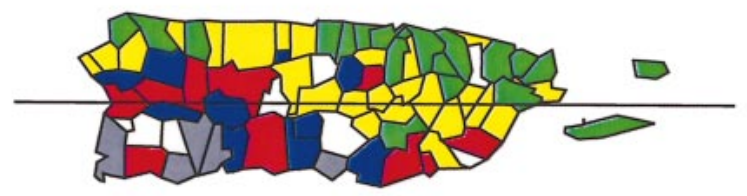

b) P1928

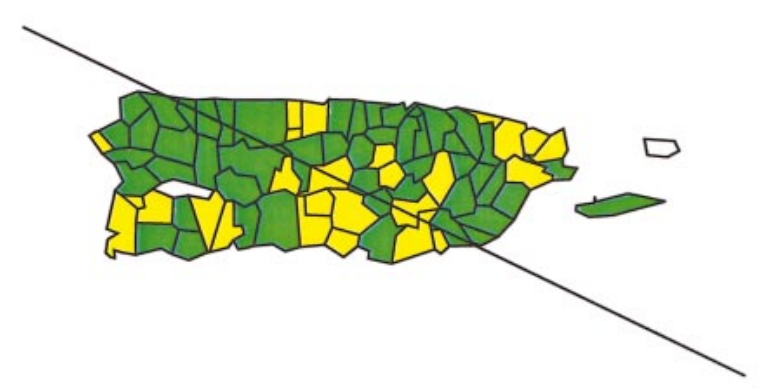

d) P1956

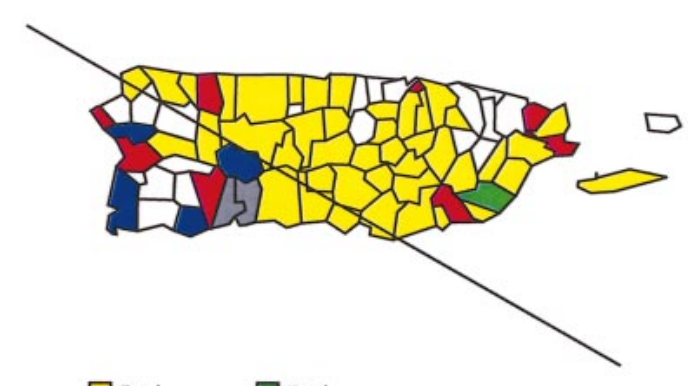

$\square$ No damage $\square$ Fo damage $\square$ F1 damage $\square$ F2 damage $\square$ F3 damage

FIG. 4. Regional patterns of actual wind damage by municipality for selected major hurricanes: (a) P1899, (b) P1928, (c) P1932, and (d) P1956.

more severe in the LEF than in Mayaguez, as one would expect from the regional gradients previously described. For example, F3 damage was estimated to occur three times in the LEF and only once in Mayaguez over the period 1851-1997.

Peak hurricane wind directions were also compared for the two sites (Fig. 9). The plot for the LEF showed peak winds above F1 mostly from the northwest and northeast quadrants, with the highest winds from the northeast quadrant (i.e., storms passing to the southwest). The plot for Mayaguez also showed peak winds above F1 mostly from the northwest and northeast quadrants, with the highest winds from the northwest quadrant (i.e., storms passing to the northeast). At both sites, peak hurricane winds were concentrated in certain directions.

At a landscape scale, the role of local topography in modifying hurricane impacts was investigated for the LEF with the EXPOS model (Fig. 10). For the three hurricanes that were estimated to cause F3 damage, $26 \%$ of the landscape within the LEF boundary was predicted to be exposed to all three storms (average return interval $=50$ years), $30 \%$ was exposed to two storms (75 years), $22 \%$ was exposed to one storm (150 years), and $22 \%$ was protected from all three storms ( $>150$ years). The combination of constrained peak wind directions and steep topography produced striking differences in the predicted impacts on the north and south slopes of the Luquillo mountains.

\section{Discussion}

\section{Historical-modeling method}

Historical completeness. - The most difficult problem in using historical materials to reconstruct hurricane regimes is estimating the completeness of the early records. Given the frequency of hurricanes in Puerto Rico, it is quite possible that all records of a storm before 1851 were lost, especially if the storm did not cause extensive damage. Many early storms that reportedly did cause extensive damage were not included in this study because specific examples of damage were not given or the cause (wind, flooding, or landslide) was not specified. However, there is reason to believe that the historical record of hurricanes that caused F3 damage in San Juan may be complete, because such storms are mentioned in the earliest records. In the future, as work on HURDAT continues, it may be possible to reconstruct hurricanes before 1851 . There are also vast historical records in the Archives of the Indies in Seville, Spain that remain largely untouched by historians but that may someday shed more light on Ca- 
TABle 2. Dates, maximum reported damage, and meteorological characteristics for the 85 hurricanes investigated in this study.

\begin{tabular}{|c|c|c|c|c|c|c|}
\hline Hurricane & No. $\dagger$ & Date $\neq$ & Name & Fmax $\S$ & $\mathrm{SS} \|$ & Track\| \\
\hline P1508 & & $26 \mathrm{Aug}$ & S. Roque & F0* & & \\
\hline P1526 & & 14 Oct & S. Francisco & F3 & & \\
\hline P1530 & & 5 Aug & S. Ana & F3 & & \\
\hline P1568 & & $3 \mathrm{Sep}$ & S. Bartolome & $\mathrm{F} 1 *$ & & \\
\hline P1615 & & 12 Sep & S. Leoncio II & F3 & & \\
\hline P1626 & & $15 \mathrm{Sep}$ & S. Nicomedes & F3 & & \\
\hline P1641 & & unknown & & $\mathrm{F} 0 *$ & & \\
\hline P1642 & & Sep & & F3 & & \\
\hline P1657 & & Aug & & $\mathrm{F} 1 *$ & & \\
\hline P1673 & & unknown & & $\mathrm{F} 1$ & & \\
\hline P1678 & & unknown & & F1 & & \\
\hline P1718 & & 7 Sep & S. Regina & $\mathrm{F} 1$ & & \\
\hline $\mathrm{P} 1738 \mathrm{a}$ & & 30 Aug & S. Rosa II & $\mathrm{F} 2$ & & \\
\hline $\mathrm{P} 1738 \mathrm{~b}$ & & 12 Sep & S. Leoncio III & $\mathrm{F} 1 *$ & & \\
\hline P1740a & & 3 Aug & S. Esteban & $\mathrm{F} 2$ & & \\
\hline $\mathrm{P} 1740 \mathrm{~b}$ & & $11-12$ Sep & S. Vicente & F0* & & \\
\hline P1742 & & 28 Oct & S. Judas Tadeo & $\mathrm{F} 1 *$ & & \\
\hline $\mathrm{P} 1751$ & & $18 \mathrm{Aug}$ & S. Agapito, Elena & $\mathrm{F} 1$ & & \\
\hline P1766 & & 19 Sep & S. Jenaro & F3 & & \\
\hline P1767 & & 7 Aug & S. Cayetano & $\mathrm{F} 1 *$ & & \\
\hline P1772a & & 28 Aug & S. Agustin & $\mathrm{F} 2 *$ & & \\
\hline $\mathrm{P} 1772 \mathrm{~b}$ & & 31 Aug & S. Ramon Nonato II & $\mathrm{F} 2$ & & \\
\hline P1775 & & 1 Aug & S. Pedro & $\mathrm{F} 2$ & & \\
\hline P1780 & & 13 Jun & S. Antonio & $\mathrm{F} 1 *$ & & \\
\hline P1785 & & 25 Sep & S. Lupo & $\mathrm{F} 1 *$ & & \\
\hline P1805 & & 11 Sep & S. Vicente II & $\mathrm{F} 2 *$ & & \\
\hline P1806 & & 11 Sep & S. Vicente III & $\mathrm{F} 2$ & & \\
\hline P1807 & & 17-19 Aug & S. Jacinto, Agapito & $\mathrm{F} 2 *$ & & \\
\hline P1812a & & $23 \mathrm{Jul}$ & S. Liborio & $\mathrm{F} 0 *$ & & \\
\hline $\mathrm{P} 1812 \mathrm{~b}$ & & $21 \mathrm{Aug}$ & S. Juana & $\mathrm{F} 0 *$ & & \\
\hline P1813a & & $23 \mathrm{Jul}$ & S. Liborio II & $\mathrm{F} 1$ & & \\
\hline P1813b & & $21 \mathrm{Aug}$ & S. Juana II & $\mathrm{F} 1$ & & \\
\hline P1814 & & $23 \mathrm{Jul}$ & S. Liborio III & F0 & & \\
\hline P1816 & & $18-20 \mathrm{Sep}$ & S. Prisca, Jose & $\mathrm{F} 2$ & & \\
\hline P1819 & & $21 \mathrm{Sep}$ & S. Mateo III & F3 & & \\
\hline P1824 & & 8 Sep & La Monserrate & $\mathrm{F} 2$ & & \\
\hline P1825 & & $26 \mathrm{Jul}$ & S. Ana II & F3 & & \\
\hline P1826 & & 1 Sep & & $\mathrm{F} 1$ & & \\
\hline P1827 & & 17 Aug & S. Jacinto II & $\mathrm{F} 2$ & & \\
\hline P1829 & & unknown & & $\mathrm{F} 1$ & & \\
\hline P1835 & & 13 Aug & S. Hipolito & $\mathrm{F} 2$ & & \\
\hline P1837 & & 2 Aug & Los Angeles & $\mathrm{F} 2$ & & \\
\hline P1867 & 8 & 29 Oct & S. Narciso & $\mathrm{F} 1$ & 2 & land \\
\hline P1871 & 4 & $21 \mathrm{Aug}$ & S. Juana III & $\mathrm{F} 1$ & 3 & $\mathrm{NE}$ \\
\hline P1876 & 2 & 13 Sep & S. Felipe & F3 & 3 & land \\
\hline P1889a & 4 & 3-4 Sep & S. Martin d. Hinojosa & $\mathrm{F} 1$ & 1 & $\mathrm{NE}$ \\
\hline $\mathrm{P} 1889 \mathrm{~b}$ & 6 & 12-13 Sep & & F0 & 1 & $\mathrm{~S}$ \\
\hline P1891a & 3 & 19-20 Aug & S. Magin & $\mathrm{F} 1$ & 2 & land \\
\hline P1891b & 10 & 14 Oct & & $\mathrm{F} 1$ & 2 & $\mathrm{E}$ \\
\hline P1893 & 3 & 16-17 Aug & S. Roque III & $\mathrm{F} 2$ & 3 & land \\
\hline P1894a & 3 & 21-22 Sep & & $\mathrm{F} 2$ & 3 & SW \\
\hline P1894b & 5 & $13-14$ Oct & & $\mathrm{F} 2$ & 2 & $\mathrm{NE}$ \\
\hline P1896 & 2 & $1 \mathrm{Sep}$ & S. Ramon Nonato III & $\mathrm{F} 1$ & 2 & land \\
\hline P1899 & 2 & 8 Aug & S. Ciriaco & $\mathrm{F} 3$ & 4 & land \\
\hline P1901 & 3 & $7 \mathrm{Jul}$ & S. Cirilo & F0 & 1 & land \\
\hline P1909 & 5 & $22 \mathrm{Aug}$ & & $\mathrm{F} 1$ & 1 & $\mathrm{~S}$ \\
\hline P1910 & 2 & 6-7 Sep & S. Zacarias II & $\mathrm{F} 2$ & 2 & $\mathrm{~S}$ \\
\hline P1915 & 2 & $11 \mathrm{Aug}$ & S. Tiburcio & $\mathrm{F} 2$ & 2 & $\mathrm{~S}$ \\
\hline P1916a & 5 & $22 \mathrm{Aug}$ & S. Hipolito II & $\mathrm{F} 2$ & 3 & land \\
\hline P1916b & 12 & 9 Oct & & F0 & 2 & $\mathrm{E}$ \\
\hline P1921 & 3 & 9-11 Sep & S. Pedro Claver II & $\mathrm{F} 2$ & 2 & $\mathrm{~W}$ \\
\hline P1926 & 1 & 23-24 Jul & S. Liborio IV & $\mathrm{F} 2$ & 2 & land \\
\hline P1928 & 4 & 13-14 Sep & S. Felipe II & F3 & 5 & land \\
\hline P1931 & 6 & $10-11$ Sep & S. Nicolas & $\mathrm{F} 2$ & 1 & land \\
\hline P1932 & 7 & 26-27 Sep & S. Cipriano II & F3 & 4 & land \\
\hline P1933 & 5 & $26 \mathrm{Jul}$ & S. Ana III & F0 & 1 & $\mathrm{NE}$ \\
\hline P1943 & 9 & 14 Oct & S. Calixto II & $\mathrm{F} 1$ & 1 & W \\
\hline
\end{tabular}


TABle 2. Continued.

\begin{tabular}{|c|c|c|c|c|c|c|}
\hline Hurricane & No. $\dagger$ & Date $\neq$ & Name & Fmax $\S$ & $\mathrm{SS} \|$ & Track $\mathbb{I}$ \\
\hline P1949 & 9 & 21-22 Sep & S. Mateo IV & $\mathrm{F} 2$ & 1 & SW \\
\hline P1950 & 4 & 2 Sep & Dog & F0 & 3 & $\mathrm{NE}$ \\
\hline P1955 & 2 & 6-7 Aug & Connie & $\mathrm{F} 1$ & 4 & $\mathrm{NE}$ \\
\hline P1956 & 3 & 12 Aug & Betsy & F3 & 3 & land \\
\hline P1960 & 5 & 5 Sep & Donna & $\mathrm{F} 2$ & 4 & $\mathrm{NE}$ \\
\hline P1963 & 6 & 26-27 Sep & Edith & $\mathrm{F} 1$ & 1 & SW \\
\hline P1964 & 5 & $23 \mathrm{Aug}$ & Cleo & F0* & 5 & $\mathrm{~S}$ \\
\hline P1966 & 9 & $28 \mathrm{Sep}$ & Inez & F1 & 4 & $\mathrm{~S}$ \\
\hline P1967 & 2 & 9-10 Sep & Beulah & $\mathrm{F} 1$ & 4 & SW \\
\hline P1975 & 5 & 15-16 Sep & Eloise & $\mathrm{F} 2$ & 1 & $\mathrm{~N}$ \\
\hline P1979 & 4 & $30-31$ Aug & David & $\mathrm{F} 2$ & 5 & SW \\
\hline P1980 & 1 & 4-5 Aug & Allen & $\mathrm{F} 2$ & 5 & SW \\
\hline P1988 & 8 & $10-11$ Sep & Gilbert & $\mathrm{F} 2$ & 2 & SW \\
\hline P1989 & 8 & $18 \mathrm{Sep}$ & Hugo & F3 & 3 & land \\
\hline P1995a & 12 & 5-6 Sep & Luis & $\mathrm{F} 1$ & 4 & $\mathrm{NE}$ \\
\hline P1995b & 13 & 15-16 Sep & Marilyn & $\mathrm{F} 2$ & 2 & $\mathrm{NE}$ \\
\hline P1996a & 2 & $8 \mathrm{Jul}$ & Bertha & $\mathrm{F} 2$ & 1 & $\mathrm{NE}$ \\
\hline P1996b & 8 & $9-10$ Sep & Hortense & $\mathrm{F} 2$ & 1 & land \\
\hline \multicolumn{7}{|c|}{$\begin{array}{l}\dagger \text { Tropical cyclone number in HURDAT. } \\
\$ \text { Date of landfall or closest approach to Puerto Rico (Gregorian calendar). } \\
\S \text { Maximum reported damage in Puerto Rico (asterisk }[*]=\text { based on regional report). } \\
\text { || Saffir-Simpson category at landfall or closest approach to Puerto Rico. } \\
\text { II The hurricane track made landfall (land) or passed to north (N), northeast (NE), etc. of } \\
\text { uerto Rico. }\end{array}$} \\
\hline
\end{tabular}

ribbean hurricanes during the colonial period (Marx 1983).

Damage assessment.- In this study, Fujita-scale values were assigned to entire municipalities on the basis of historical reports of wind damage. Potential sources of error are as follows. (1) Damage levels may be overestimated if the object damaged was weak or defective before the storm. This problem is most likely to occur on a broad scale when two or more severe storms strike over a short period of time; e.g., some of the buildings that failed in 1932 may have been weakened by previous hurricanes in 1928 and 1931 (NWS 1932). Failure to exclude damage caused by landslides, river flooding, or storm surge may also lead to overestimation of the level of wind damage. (2) Damage levels may be underestimated if examples of higher damage are not reported. F-scale values may tend to be higher

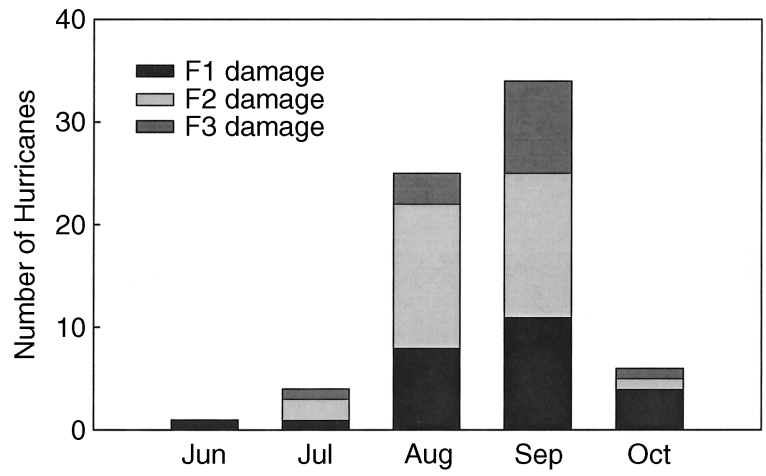

FIG. 5. Seasonal distribution of hurricanes with maximum reported damage on the Fujita scale equal to F1 or higher (1508-1997), showing date of landfall or closest approach to Puerto Rico (Gregorian calendar). for more populated areas where there are more observers, more property subject to potential damage, and better records. In at least one case (P1876), the government of Puerto Rico decided not to disclose the full extent of the damage in order to avoid a negative impact on commerce (Salivia 1950). (3) Systematic errors may occur because of differences in construction practices over time, or from place to place. The susceptibility of a particular building to wind damage is a complex function of building design and construction quality, as well as state of repair, wind direction, topographic position, surrounding wind breaks, and whether or not doors and windows are open, closed, or shuttered (Liu 1993). Unfortunately, this information is generally unavailable from historical sources. Finally, (4) random errors may result from inaccuracies in the historical accounts.

The problems just described arise mainly from the need to rely on nonsystematic written records and photographs for damage assessment. However, the basic technique was found to work well for the purposes of this study, largely because the Fujita damage classes are so broad. The overall tendency for the model to overestimate damage probably resulted from the underreporting of actual damage, especially from smaller municipalities.

Meteorological modeling.-Meteorological modeling complements wind damage assessment by providing informed estimates for sites that lack actual observations, as well as a complete picture of the estimated impacts of each hurricane on a regional scale. Potential sources of error include the following. (1) The HURRECON model is based on an idealized wind profile that works best for intense hurricanes. The model is not able to reconstruct multiple wind maxima or 
a) All Hurricanes

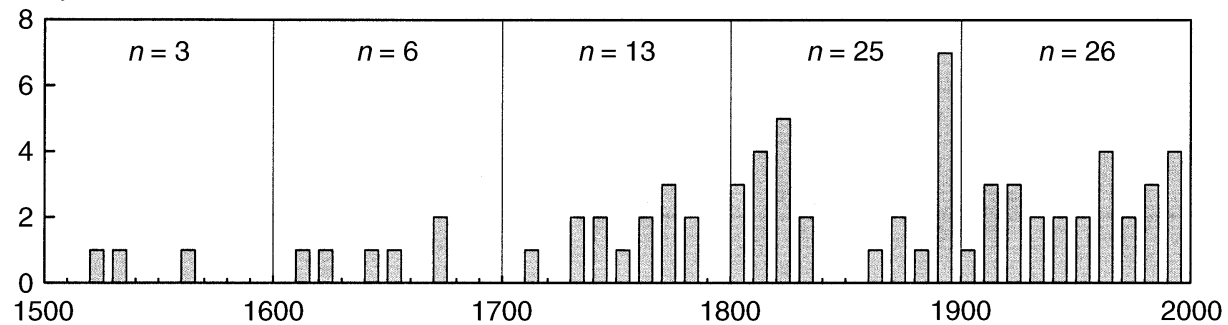

b) F3 Damage

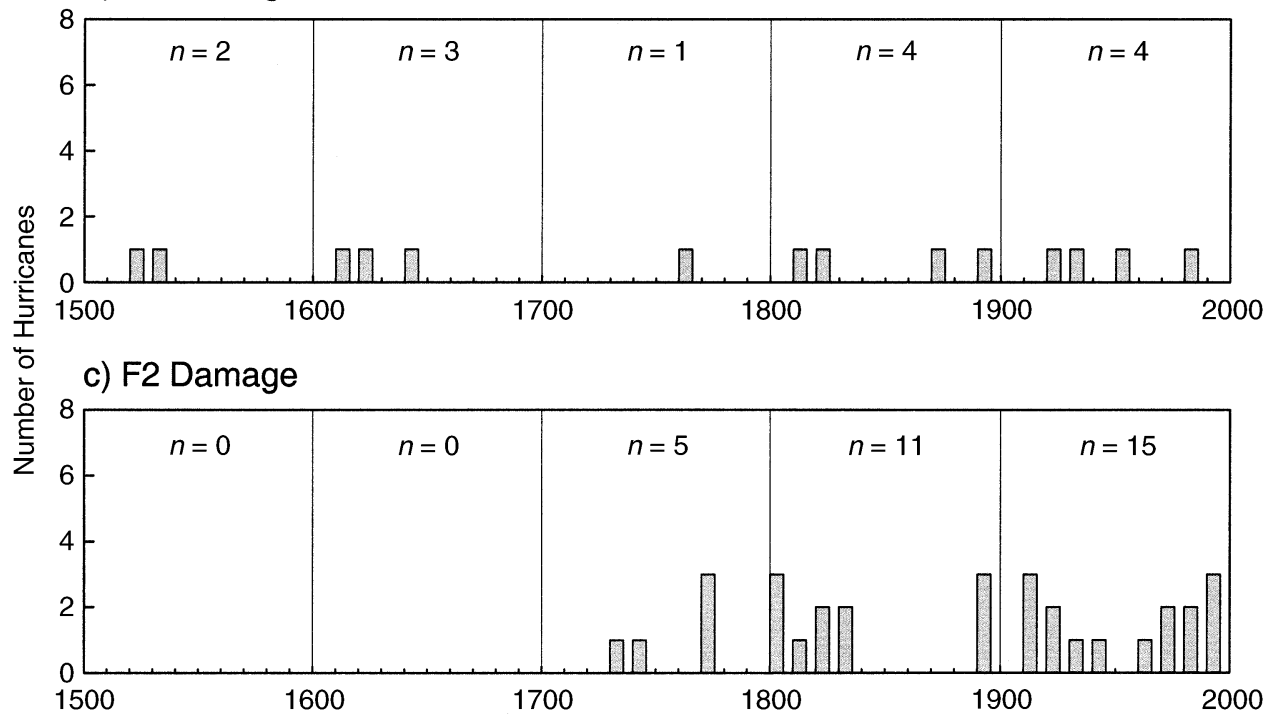

d) F1 Damage

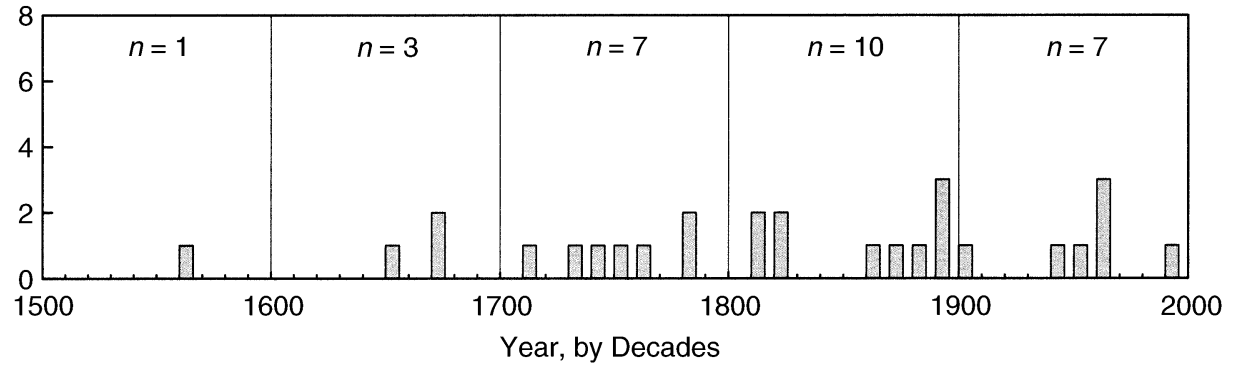

FIG. 6. Number of hurricanes by decade (1508-1997) over the entire study area with maximum reported damage on the Fujita scale equal to (a) F1 or higher, (b) F3, (c) F2, and (d) F1.

other mesoscale features (Willoughby 1995). (2) Damage estimates are based on peak 0.25-mile wind speed following Fujita's method (1971), which assumes that the period of sustained wind required to produce specific damage is inversely proportional to wind speed. This approach yields wind durations appropriate for tree and building damage (e.g., 12 seconds for minimal hurricane force winds), but does not take into account fatigue and stress damage that may occur on a scale of minutes or hours. Nor does it account for damage caused by a shift in wind direction (Powell et al. 1995). (3) Puerto Rico is too small to provide good evidence for the radius of maximum winds $\left(R_{\mathrm{m}}\right)$ except for hur- ricanes that make landfall or pass very close to the island. Although the four combinations of $R_{\mathrm{m}}$ and $B$ used in this study enabled a good fit between actual and reconstructed damage for Puerto Rico, there is, in general, no correlation between these two parameters. A more accurate estimate of $R_{\mathrm{m}}$ and $B$ would require data from a much larger area. (4) Regional gradients of reconstructed hurricane frequency at higher damage levels were a direct consequence of the simulated weakening of hurricanes that passed over the island. Although there was evidence of such weakening in nearly every case, it is unlikely that all of these storms weakened at the same rate. (5) Meteorological data are 
a) F2+ Damage

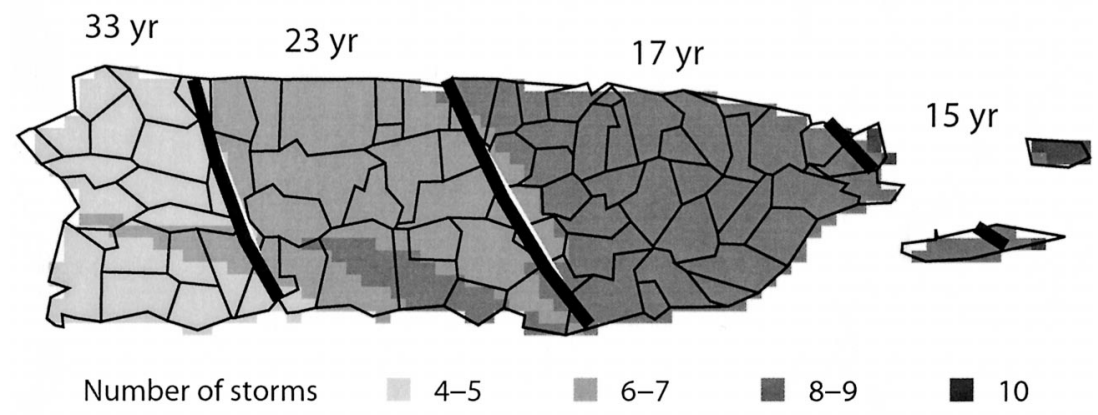

b) F3 Damage

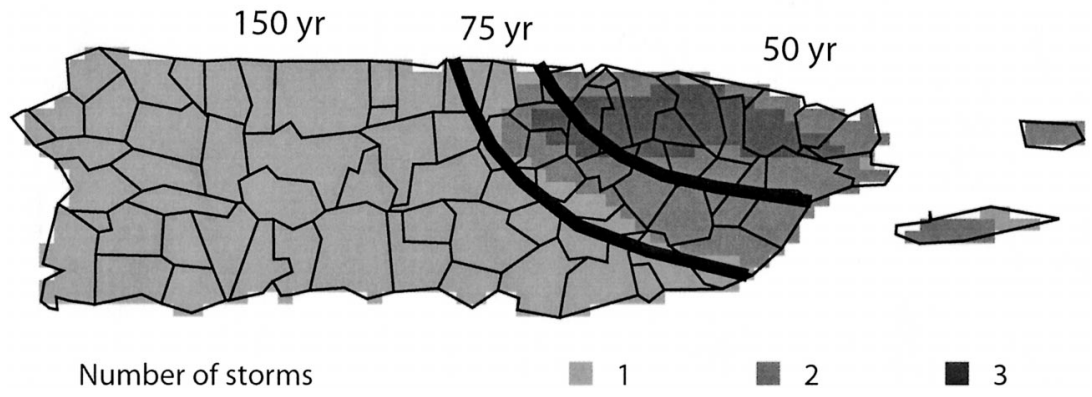

FIG. 7. Regional gradients in reconstructed hurricane damage (1851-1997) using best-fit values for $R_{\mathrm{m}}$ and $B$, showing numbers of storms and average return intervals (range 15-150 years): (a) F2+ damage; (b) F3 damage.

a) Luquillo Experimental Forest

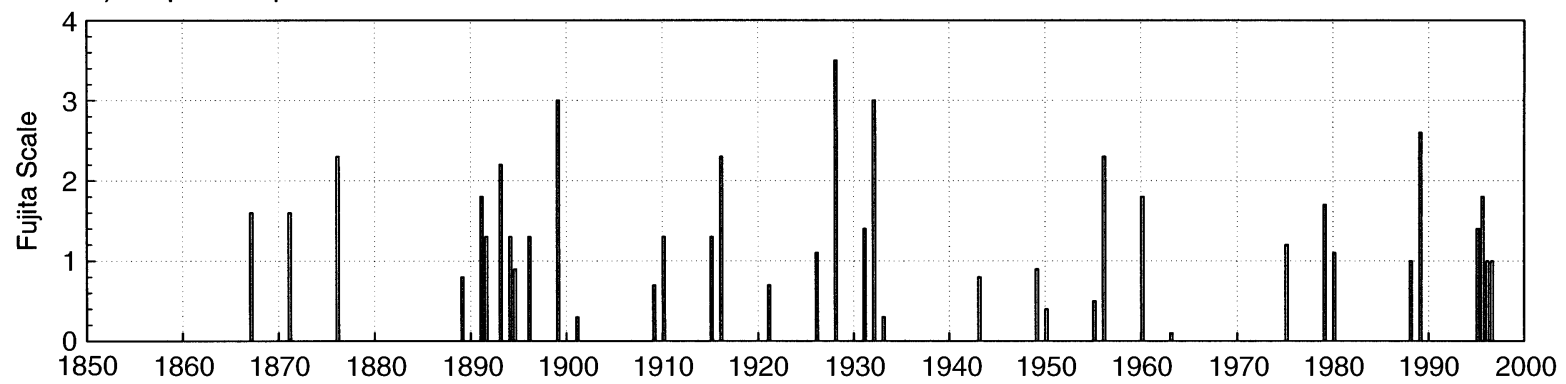

b) Mayaguez

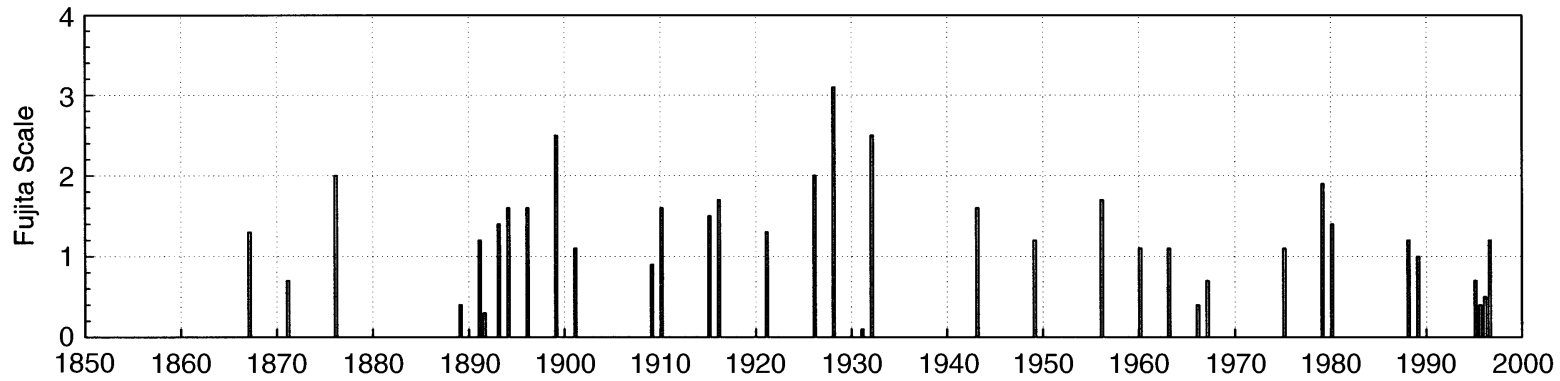

FIG. 8. Time lines of reconstructed hurricane damage on the Fujita scale by year for (a) Luquillo Experimental Forest and (b) Mayaguez, Puerto Rico. 
a) Luquillo Experimental Forest

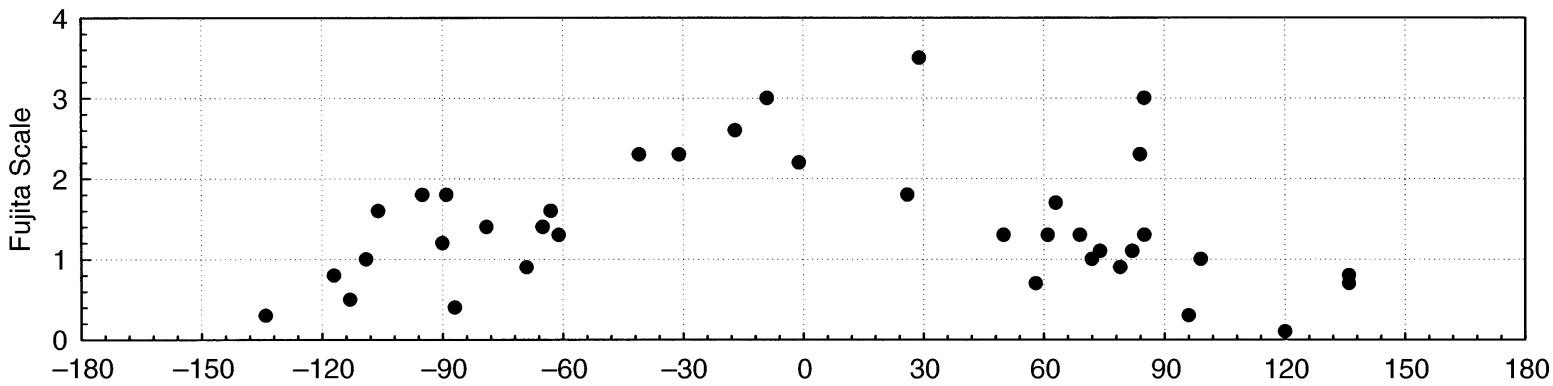

b) Mayaguez

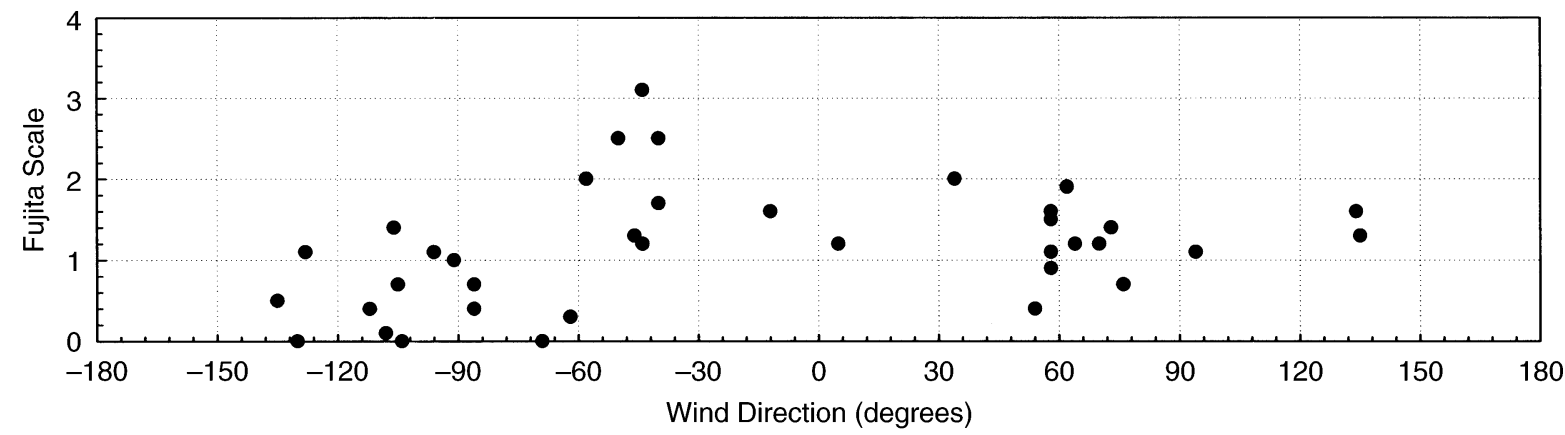

FIG. 9. Reconstructed hurricane damage on the Fujita scale by peak wind direction (1851-1997) for (a) Luquillo Experimental Forest and (b) Mayaguez. Each point represents one hurricane.

more accurate for more recent hurricanes, especially since the advent of aerial reconnaissance (1944) and continuous satellite coverage (mid-1960s; Landsea 1993).

Despite these problems, regional maps of actual and reconstructed damage were found to agree closely for the hurricanes modeled. This agreement was no doubt enhanced by the small number of predicted damage classes (no damage, F0, F1, F2, F3); a larger number of classes would provide a more robust test of the model, but this was not practical, given the nature of the historical materials.

\section{Ecological significance for Puerto Rico}

Regional impacts.-Historical evidence suggests that Puerto Rico experiences frequent and intense disturbance from hurricane winds. Loss of foliage and branches $(\mathrm{F} 0+)$ or scattered blowdowns and small gaps $(\mathrm{F} 1+)$ occur every $4-6$ years across the island. At higher damage levels, a regional gradient from northeast to southwest results from the consistent direction of the storms tracks and the tendency for hurricanes to weaken over the interior mountains. Extensive blowdowns and large gaps $(\mathrm{F} 2+)$ occur about twice as often in the northeast (15 years) as in western sections (33 years); whereas forest leveling (F3) occurs about three times as often in the northeast (50 years) as in western sections (150 years). Except in topographically protected areas, most trees are subject to repeated minor damage on a scale of years, and major damage or mortality on a scale of decades.

At a regional scale, the impact of these events is controlled by broad-scale differences in natural vegetation and in land-use and disturbance history. For example, the scrub forests of the dry southwest may be more resilient to wind damage because of their shorter stature and open-growth forms. Similarly, high-elevation forests in the LEF, particularly the dwarf forest on the highest peaks and ridge tops, may be more windresistant because of their reduced height and routine exposure to higher wind speeds, although they may also be subject to higher winds during a hurricane. Extensive deforestation along the coastal plain and at lower elevations, culminating in the early 20th century (Wadsworth 1950), greatly reduced the extent of natural forest subject to wind disturbance, while at the same time increasing exposure for remaining trees, orchards, and crops.

Site and landscape impacts.-On a landscape scale, the impacts of hurricane winds may be greatly modified by local topography. Hilly or mountainous terrain may provide local protection from certain wind directions, and such protection may be long-term if the damaging winds come from the same direction in most or all hurricanes. In the LEF, the highest hurricane winds tend to come from the northeast (northwest to east), because of the direction of the storm tracks, the inward spiraling of winds at the surface, and the tendency for hurricanes 
a) North-facing Slopes

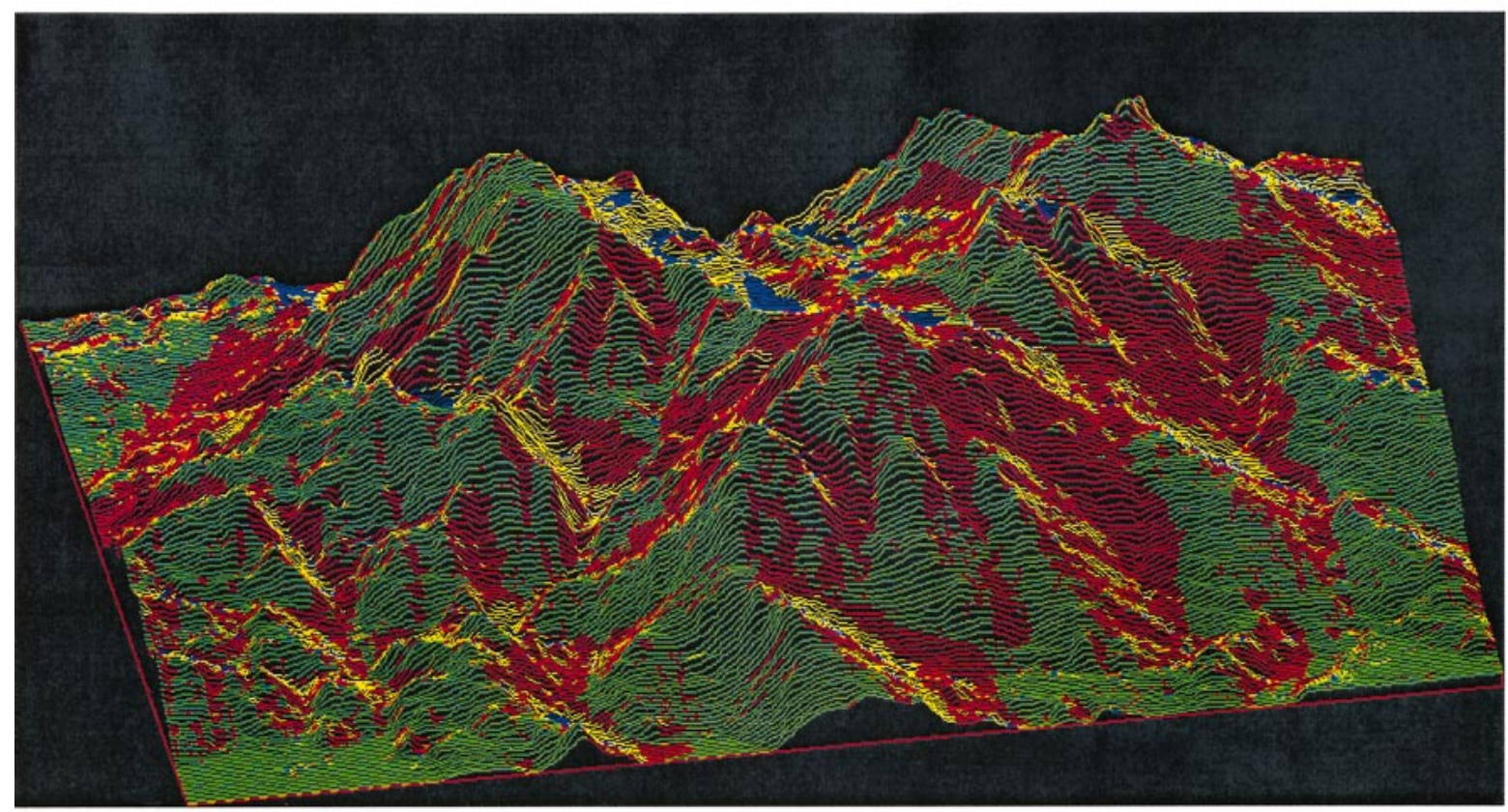

\section{b) South-facing Slopes}

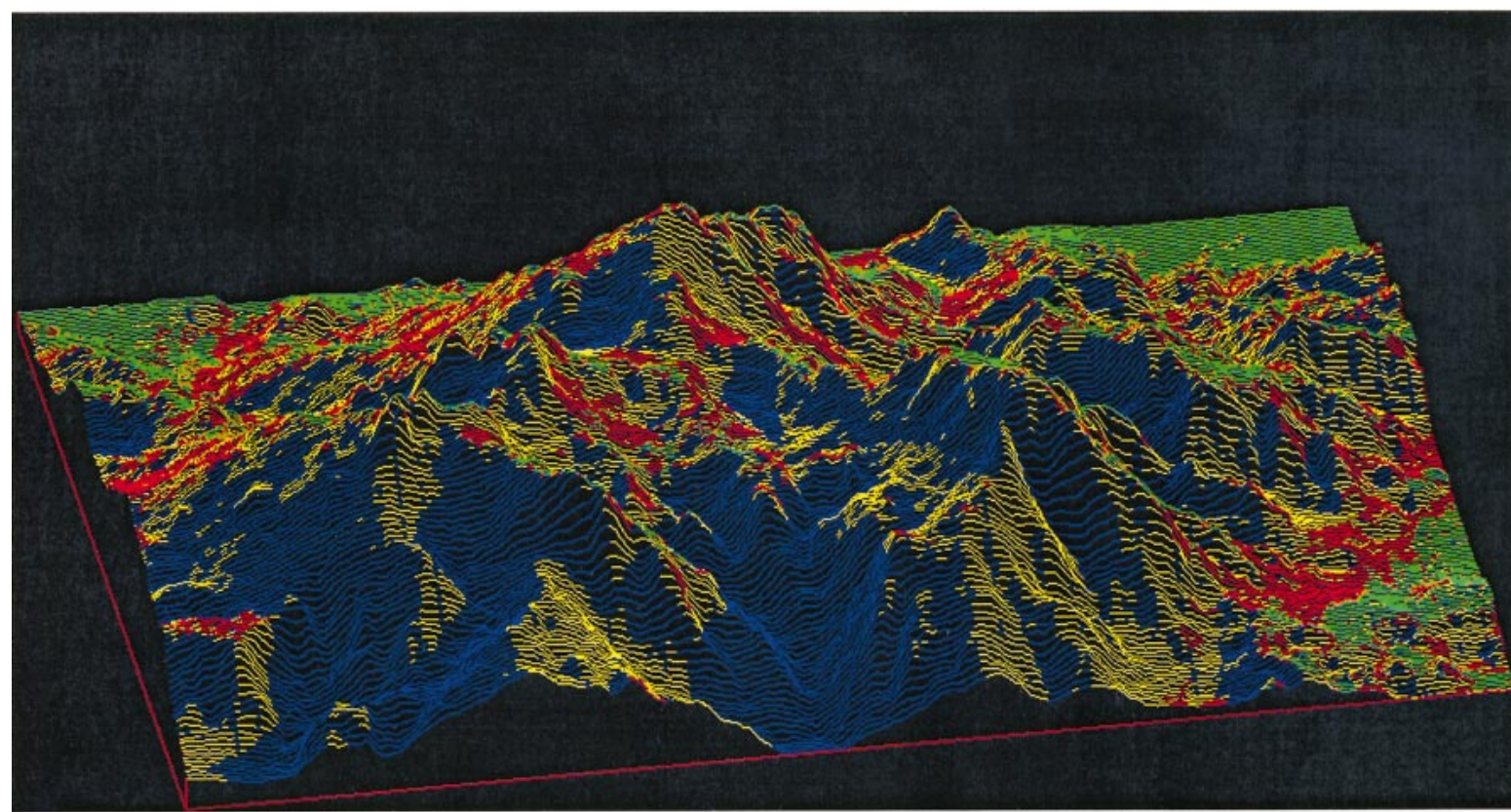

$>150 \mathrm{yr}$

$150 \mathrm{yr}$

$75 \mathrm{yr}$

$50 \mathrm{yr}$

FIG. 10. Landscape gradients in reconstructed F3 damage for the Luquillo Experimental Forest (1851-1997) using the EXPOS model, showing average return intervals (range 50 to $>150$ years) for (a) north-facing slopes and (b) south-facing slopes. 
to weaken over land. The result is a strong landscapescale gradient of predicted impacts, with extended areas on the southern slopes and pockets on the northern slopes protected from the most damaging winds. Actual forest damage will be influenced by previous disturbance and land-use history: like other disturbances, hurricanes both create and respond to spatial heterogeneity (Turner et al. 2003). Although all of the LEF has been affected by human land use (Foster et al. 1999), and the legacies of past land use may persist through several episodes of natural disturbance (Foster et al. 2003), the ecological consequences of topographic protection from hurricane winds might be discernible at higher elevations where human land use has been less extensive.

At finer spatial scales, the effects of terrain on wind flow may be complex and difficult to predict. For example, in Hurricane Hugo (P1989), there was evidence of wind deflection around local peaks and channeling along river valleys in the LEF (Boose et al. 1994), with severe damage on summit ridges perpendicular to the wind (E. R. Boose, personal observation). In Hurricane Betsy (P1956), valleys sometimes sustained more damage than neighboring ridges, presumably because of taller trees resulting from better soils (Grace 1956, Wadsworth and Englerth 1959). Unfortunately, such patterns are virtually impossible to discern for earlier hurricanes because of the lack of spatial information on forest damage in the historical record, the rapid recovery of Puerto Rican forests, and the obscuration of earlier damage by successive storms.

At the stand level, damage caused by winds of a given speed and duration varies as a function of stand composition and structure, which, in turn, are strongly influenced by land-use and natural disturbance history. Forest damage from Hurricane Hugo (P1989), for example, was no doubt enhanced by increases in forest cover and height that resulted from farm abandonment and a lull in hurricane activity in preceding decades (Foster et al. 1999). At the species level, susceptibility to wind damage varies greatly. Key factors appear to be plant architecture (size, shape, strength), which makes some species (e.g., palms) more resistant to wind damage; and rate of defoliation, which greatly reduces wind drag (Francis and Gillespie 1993). At the individual plant level, rooting conditions (soil depth and moisture) and growth form influence a tree's resistance to wind throw (Weaver 1989).

Comparisons with New England.-Puerto Rico and New England, both located in the North Atlantic hurricane basin and occasionally subject to the same storms, provide interesting examples of tropical and temperate hurricane disturbance regimes (cf. Boose et al. 2001, Boose 2003). For example, the following differences over the historical period between the LEF (northeastern Puerto Rico) and the Harvard Forest (central Massachusetts) are ecologically significant. (1) The LEF is subject to more frequent and more intense hur- ricane wind damage. Although the frequency of $\mathrm{F} 0+$ damage is comparable, the LEF experiences F1+ damage three times as often and F2+ damage eight times as often as Harvard Forest; whereas F3 damage, which is rare and isolated in New England, occurs about every 50 years in the LEF. (2) The average forward velocity of hurricanes in New England is about three times the velocity in Puerto Rico; thus (for storms of equal size and strength) damaging winds in Puerto Rico last about three times as long. (3) Most hurricanes in Puerto Rico occur in August and September, whereas in New England about one quarter of all hurricanes occur in October and November, when leaf senescence dramatically changes the susceptibility of hardwoods to wind damage. (4) In the LEF, the steep mountain topography in close proximity to the ocean creates dramatic patterns of topographic exposure, with extended protected areas, whereas in central New England, most of the gently rolling landscape is fully exposed to hurricane winds. (5) The year-round warm temperatures and high precipitation of the LEF create high rates of regeneration and decomposition, so that even catastrophic damage disappears from casual view in a matter of years. In New England, on the other hand, recovery from wind damage is much slower and the effects of past storms may be visible for decades.

\section{ACKNOWLEDGMENTS}

The authors thank K. Chamberlin, L. Hoffman, M. Montalvo, and R. Ramos for assistance with the historical research; B. Slater and J. Thomlinson for help with the GIS data; B. Hall for assistance with figure preparation; and W. Lauenroth and two anonymous reviewers for invaluable comments on the manuscript. The research was supported by grants from the National Science Foundation (DEB-9318552, DEB-9411975, and DEB-9411973) and is a contribution from the Harvard Forest and Luquillo Long-Term Ecological Research Programs.

\section{Literature Cited}

Anthes, R. A. 1982. Tropical cyclones: their evolution, structure and effects. American Meteorological Society, Boston, Massachusetts, USA.

Asenjo, F. 1886. Efemerides de la Isla de Puerto Rico. San Juan, Puerto Rico.

Bates, C. G. 1930. Hurricane damage to Porto Rican forests. Journal of Forestry 28:772-774.

Birdsey, R. A., and P. L. Weaver. 1982. The forest resources of Puerto Rico. USDA Forest Service Resource Bulletin SO-85

Boose, E. R. 2003. Hurricane impacts in New England and Puerto Rico. Pages 25-42 in D. Greenland, D. Goodin, and R. C. Smith, editors. Climate variability and ecosystem response at Long-Term Ecological Research sites. Oxford University Press, Oxford, UK.

Boose, E. R., K. E. Chamberlin, and D. R. Foster. 1997. Reconstructing historical hurricanes in New England. Pages 388-389 in Preprints of the 22nd Conference on Hurricanes and Tropical Meteorology. American Meteorological Society, Boston, Massachusetts, USA.

Boose, E. R., K. E. Chamberlin, and D. R. Foster. 2001. Landscape and regional impacts of hurricanes in New England. Ecological Monographs 71:27-48.

Boose, E. R., D. R. Foster, A. Barker Plotkin, and B. Hall. 2003. Geographical and historical variation in hurricanes 
across the Yucatan Peninsula. Pages 495-516 in A. GómezPompa, M. F. Allen, S. Fedick, and J. J. Jiménez-Osornio, editors. Lowland Maya area: three millennia at the humanwildland interface. Haworth Press, New York, New York, USA.

Boose, E. R., D. R. Foster, and M. Fluet. 1994. Hurricane impacts to tropical and temperate forest landscapes. Ecological Monographs 64:369-400.

Brau, Salvador. 1904. Historia de Puerto Rico. D. Appleton, New York, New York, USA.

Coll y Toste, C. 1914-1927. Boletin Historico de Puerto Rico. 14 volumes. San Juan, Puerto Rico.

Diaz, H. F., and R. S. Pulwarty, editors. 1997. Hurricanes: climate and socioeconomic impacts. Springer-Verlag, New York, New York, USA.

Dunn, G. E., and B. I. Miller. 1964. Atlantic hurricanes. Revised edition. Louisiana State University Press, Baton Rouge, Louisiana, USA.

Ewel, J. J., and J. L. Whitmore. 1973. Ecological life zones of Puerto Rico and the U.S. Virgin Islands. USDA Forest Service Research Paper ITF-18.

Fassig, O. L. 1928. San Felipe-the hurricane of September 13, 1928, at San Juan, P.R. Monthly Weather Review 56: $350-352$.

Fernandez-Partagas, J., and H. F. Diaz. 1995. A reconstruction of historical tropical cyclone frequency in the Atlantic from documentary and other historical sources 1851 to 1880. Part I (1851-1870) and Final Report. Climate Diagnostics Center, NOAA, Coral Gables, Florida, USA.

Foster, D. R., and E. R. Boose. 1992. Patterns of forest damage resulting from catastrophic wind in central New England, U.S.A. Journal of Ecology 80:79-98.

Foster, D. R., M. Fluet, and E. R. Boose. 1999. Human or natural disturbance: landscape-scale dynamics of the tropical forests of Puerto Rico. Ecological Applications 9:555572.

Foster, D. R., D. H. Knight, and J. F. Franklin. 1998. Landscape patterns and legacies resulting from large, infrequent forest disturbances. Ecosystems 1:497-510.

Foster, D. R., F. Swanson, J. Aber, I. Burke, N. Brokaw, D. Tilman, and A. Knapp. 2003. The importance of land-use legacies to ecology and conservation. BioScience 53:7788.

Francis, J. K., and A. J. R. Gillespie. 1993. Relating gust speed to tree damage in Hurricane Hugo, 1989. Journal of Arboriculture 19:368-373.

Fujita, T. T. 1971. Proposed characterization of tornadoes and hurricanes by area and intensity. SMRP (Satellite and Mesometeorology Research Project) Research Paper 91. University of Chicago Press, Chicago, Illinois, USA.

Fujita, T. T. 1987. U.S. Tornadoes: part one, 70-year statistics. SMRP (Satellite and Mesometeorology Research Project) Research Paper 218. University of Chicago Press, Chicago, Illinois, USA.

Grace, R. J. 1956. Weather notes: Betsy's roving eye. Monthly Weather Review 84:311-312.

Gray, W. M. 1990. Strong association between West African rainfall and U.S. landfalling intense hurricanes. Science 249:1251-1256.

Gray, W. M., J. D. Sheaffer, and C. W. Landsea. 1997. Climate trends associated with multidecadal variability of Atlantic hurricane activity. Pages 15-53 in H. F. Diaz and R. S. Pulwarty, editors. Hurricanes: climate and socioeconomic impacts. Springer-Verlag, New York, New York, USA.

Grazulis, T. P. 1993. Significant tornadoes 1680-1991. Environmental Films, St. Johnsbury, Vermont, USA.

Holdridge, L. R. 1946. A brief sketch of the Puerto Rican flora. Pages 81-83 in F. Verdoorn, editor. Plants and plant science in Latin America. Chronica Botanica, Waltham, Massachusetts, USA.
Holland, G. J. 1980. An analytical model of the wind and pressure profiles in hurricanes. Monthly Weather Review 108: $1212-1218$.

Jarvinen, B. R., C. J. Neumann, and M. A. S. Davis. 1984. A tropical cyclone data tape for the North Atlantic Basin, 1886-1983: contents, limitations, and uses. NOAA Technical Memo NWS NHC 22. Coral Gables, Florida, USA.

Jopling, C. F. 1988. Puerto Rican houses in sociohistorical perspective. University of Tennessee Press, Knoxville, Tennessee, USA.

Kaplan, J., and M. DeMaria. 1995. A simple empirical model for predicting the decay of tropical cyclone winds after landfall. Journal of Applied Meteorology 34:2499-2512.

Landsea, C. 1993. A climatology of intense (or major) Atlantic hurricanes. Monthly Weather Review 121:17031713.

Landsea, C., C. Anderson, N. Charles, G. Clark, J. FernandezPartagas, P. Hungerford, C. Neumann, and M. Zimmer. 2002. Atlantic hurricane re-analysis project. NOAA/Hurricane Research Division web page. [Online: 〈http:// www.aoml.noaa.gov/hrd/hurdat $\rangle$.]

Liu, H. 1993. Calculation of wind speeds required to damage or destroy buildings. Pages 535-541 in C. Church, D. Burgess, C. Doswell, and R. Davies-Jones, editors. The tornado: its structure, dynamics, prediction, and hazards. Geophysical Monograph 79. American Geophysical Union, Washington, D.C., USA.

Lugo, A. E. 2000. Effects and outcomes of Caribbean hurricanes in a climate change scenario. Science of the Total Environment 262:243-251.

Mann, M. E., R. S. Bradley, and M. K. Hughes. 1998. Globalscale temperature patterns and climate forcing over the past six centuries. Nature 392:779-787.

Marx, R. F. 1983. Shipwrecks in the Americas. Bonanza Books, New York, New York, USA.

Millas, J. C. 1968. Hurricanes of the Caribbean and adjacent regions. Academy of the Arts and Sciences of the Americas, Miami, Florida, USA.

Neumann, C. J., B. R. Jarvinen, and A. C. Pike. 1987. Tropical cyclones of the North Atlantic ocean 1871-1986. Third revised edition. NOAA-National Climatic Data Center, Asheville, North Carolina, USA.

Neumann, C. J., and C. J. McAdie. 1997. The Atlantic tropical cyclone file: a critical need for a revision. Pages 401402 in Preprints of the 22nd Conference on Hurricanes and Tropical Meteorology, American Meteorological Society, Boston, Massachusetts, USA.

NOAA (National Oceanic and Atmospheric Administration). 1994. Global tropical/extratropical cyclone climatic atlas. CD-ROM, version 1.0. NOAA/U.S. Navy, Washington, D.C., USA.

NWS (National Weather Service). 1932. Monthly meteorological notes at San Juan, Porto Rico, for the month of September, 1932. U.S. National Climatic Data Center, Asheville, North Carolina, USA.

Powell, M. D. 1982. The transition of the Hurricane Frederic boundary-layer wind field from the open Gulf of Mexico to landfall. Monthly Weather Review 110:1912-1932.

Powell, M. D. 1987. Changes in the low-level kinematic and thermodynamic structure of Hurricane Alicia (1983) at landfall. Monthly Weather Review 115:75-99.

Powell, M. D., S. H. Houston, and I. Ares. 1995. Real-time damage assessment in hurricanes. Pages 500-502 in Preprints of the 21 st Conference on Hurricanes and Tropical Meteorology, American Meteorological Society, Boston, Massachusetts, USA.

Powell, M. D., S. H. Houston, and T. A. Reinhold. 1994. Standardizing wind measurements for documentation of surface wind fields in Hurricane Andrew. Pages 52-69 in R. A. Cook and M. Soltani, editors. Hurricanes of 1992: 
lessons learned and implications for the future. American Society of Civil Engineers, New York, New York, USA.

Salivia, L. A. 1950. Historia de los temporales de Puerto Rico (1508-1949). San Juan, Puerto Rico.

Scatena, F. N., and M. C. Larsen. 1991. Physical aspects of Hurricane Hugo in Puerto Rico. Biotropica 23:317-323.

Scatena, F. N., S. Moya, C. Estrada, and J. D. Chinea. 1996. The first five years in the reorganization of aboveground biomass and nutrient use following Hurricane Hugo in the Bisley Experimental Watersheds, Luquillo Experimental Forest, Puerto Rico. Biotropica 28:424-440.

Silver, W. L., F. N. Scatena, A. H. Johnson, T. G. Siccama, and F. Watt. 1996. At what temporal scales does disturbance affect belowground nutrient pools? Biotropica 28: $441-457$.

Simpson, R. H., and H. Riehl. 1981. The hurricane and its impact. Louisiana State University Press, Baton Rouge, Louisiana, USA.

Steudler, P. A., J. M. Melillo, R. D. Bowden, and M. S. Castro. 1991. The effects of natural and human disturbances on soil nitrogen dynamics and trace gas fluxes in a Puerto Rican wet forest. Biotropica 23:356-363.

Turner, M. G., S. L. Collins, A. L. Lugo, J. J. Magnuson, T. S. Rupp, and F. J. Swanson. 2003. Disturbance dynamics and ecological response: the contribution of long-term ecological research. BioScience 53:46-56.

Van Middeldyk, R. A. 1910. The history of Puerto Rico, from the Spaniard discovery to the American occupation. Young People's Missionary Movement of the United States and Canada, New York, New York, USA.
Wadsworth, F. H. 1950. Notes on the climax forests of Puerto Rico and their destruction and conservation prior to 1900 . Caribbean Forester 11:38-47.

Wadsworth, F. H., and G. H. Englerth. 1959. Effect of the 1956 hurricane on forests of Puerto Rico. Caribbean Forester 20:38-51.

Walker, L. R. 1991. Tree damage and recovery from Hurricane Hugo in Luquillo Experimental Forest, Puerto Rico. Biotropica 23:379-385.

Walker, L. R., N. V. L. Brokaw, D. J. Lodge, and R. B. Waide, editors. 1991. Ecosystem, plant, and animal responses to hurricanes in the Caribbean. Biotropica 23:313-521.

Walker, L. R., W. L. Silver, M. R. Willig, and J. K. Zimmerman, editors. 1996. Long-term responses of Caribbean ecosystems to disturbance. Biotropica 28:414-613.

Weaver, P. L. 1989. Forest changes after hurricanes in Puerto Rico's Luquillo mountains. Interciencia 14:181-192.

Willoughby, H. E. 1995. Mature structure and evolution. Pages 21-62 in R. L. Elsberry, editor. Global perspectives on tropical cyclones. World Meteorological Organization, Geneva, Switzerland.

Zimmerman, J. K., E. M. Everham, R. B. Waide, D. J. Lodge, C. M. Taylor, and N. V. L. Brokaw. 1994. Responses of tree species to hurricane winds in subtropical wet forest in Puerto Rico: implications for tropical tree life histories. Journal of Ecology 82:911-922.

Zimmerman, J. K., M. R. Willig, L. R. Walker, and W. L. Silver. 1996. Introduction: disturbance and Caribbean ecosystems. Biotropica 28:414-423.

\section{APPENDIX A}

A table describing adjustments to maximum sustained wind speed $\left(V_{\mathrm{m}}\right)$ values in the HURDAT database for 19 hurricanes is available in ESA's Electronic Data Archive: Ecological Archives M074-008-A1.

\section{APPENDIX B}

A table describing historical sources and actual damage by municipality for the 85 hurricanes investigated in this study is available in ESA's Electronic Data Archive: Ecological Archives M074-008-A2.

\section{APPENDIX C}

A table describing best-fit values of $R_{\mathrm{m}}$ and $B$ and differences between reconstructed and actual damage for 43 hurricanes since 1851 is available in ESA's Electronic Data Archive: Ecological Archives M074-008-A3. 